
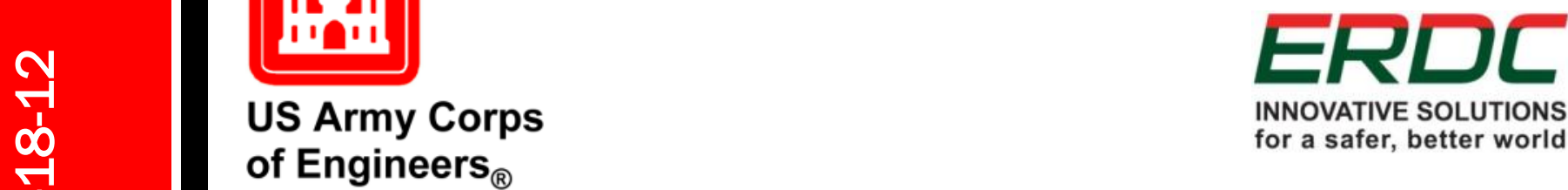

INNOVATIVE SOLUTIONS of Engineers ${ }_{\circledast}$

Engineer Research and

Development Center

\title{
Permafrost and Road Degradation in Alaska
}

Juliana M. McMillan-Wilhoit, Heidi R. Howard, and Kate A. Morozova

June 2018

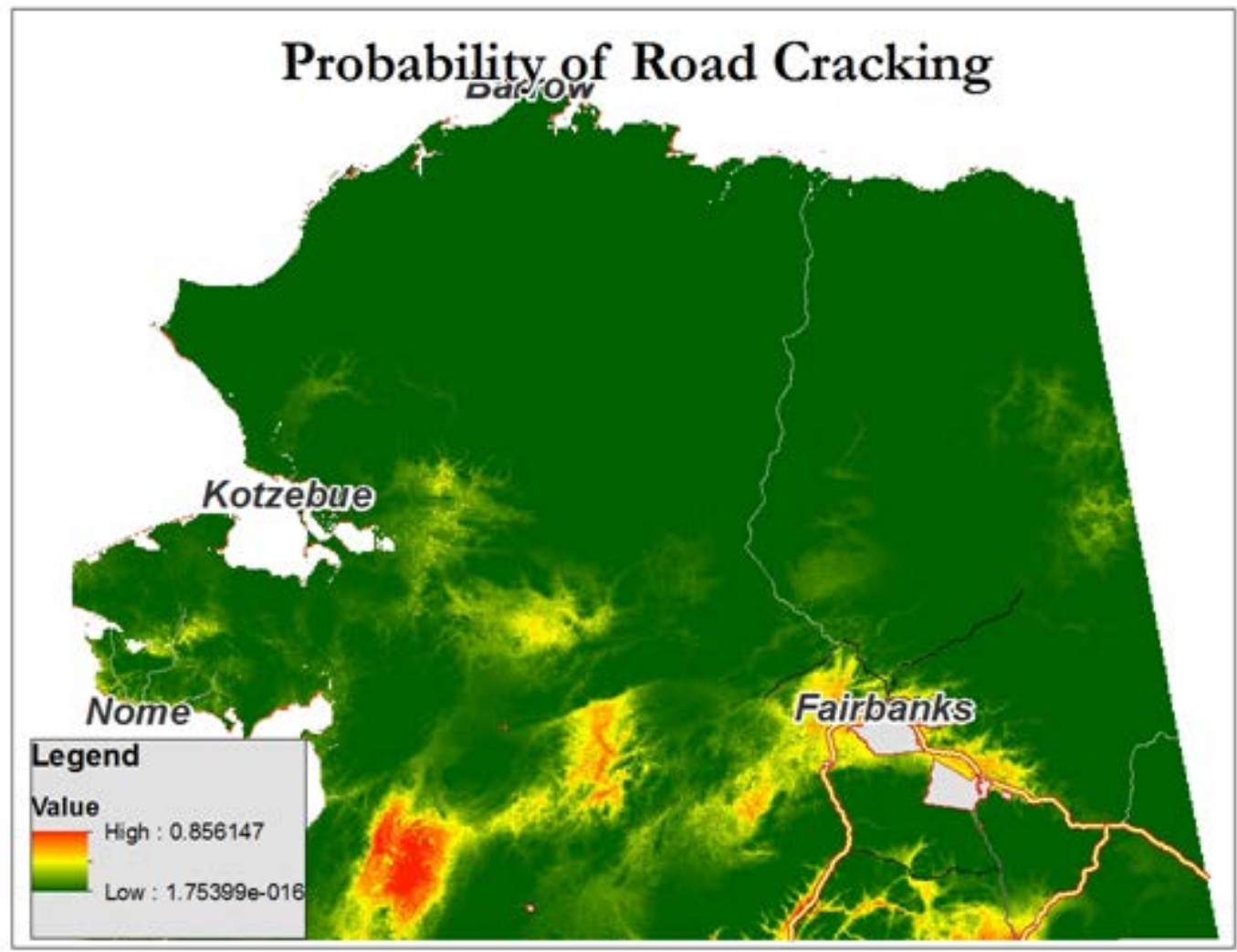

Approved for public release; distribution is unlimited. 
The U.S. Army Engineer Research and Development Center (ERDC) solves the nation's toughest engineering and environmental challenges. ERDC develops innovative solutions in civil and military engineering, geospatial sciences, water resources, and environmental sciences for the Army, the Department of Defense, civilian agencies, and our nation's public good. Find out more at www.erdc.usace.army.mil.

To search for other technical reports published by ERDC, visit the ERDC online library at http://acwc.sdp.sirsi.net/client/default. 


\section{Permafrost and Road Degradation in Alaska}

Juliana M. McMillan-Wilhoit, Heidi R. Howard, and Kate A. Morozova

U.S. Army Engineer Research and Development Center (ERDC)

Construction Engineering Research Laboratory (CERL)

2902 Newmark Dr.

Champaign, IL 61824

Final Report

Approved for public release; distribution is unlimited.

Prepared for Office of the Assistant Secretary of the Army for Acquisition, Logistics, and Technology, ASA(ALT),

Washington, DC 20310

Under Program Element 622720896, "Base Facility Environmental Quality," Work Package "Infrastructure Planning in an Arctic Domain: Mitigating the Effects of Permafrost Thaw" 


\section{Abstract}

Permafrost is rock, soil, or sediment that stays below o $\mathrm{C}$ for at least 2 consecutive years. About a quarter of the northern hemisphere's land mass is permafrost, and Alaska may be $85 \%$ permafrost. Permafrost is degrading. Uneven thaw is expected to significantly add to the current costs of road, pipeline, and airport maintenance over the next 20 years in Alaska. In the Arctic, permafrost degradation may impact training activities and increase operations and maintenance costs annually at U.S. Army installations. This work outlines a methodology to predict the probability that local infrastructure will incur damage (i.e., if a road will crack) based on the probability that the infrastructure was built on a permafrost location.

DISCLAIMER: The contents of this report are not to be used for advertising, publication, or promotional purposes. Citation of trade names does not constitute an official endorsement or approval of the use of such commercial products. All product names and trademarks cited are the property of their respective owners. The findings of this report are not to be construed as an official Department of the Army position unless so designated by other authorized documents. 


\section{Contents}

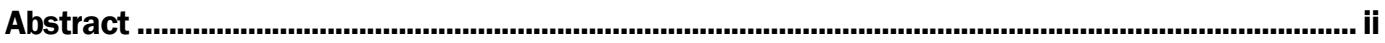

Figures and Tables........................................................................................................................

Preface .............................................................................................................................................................

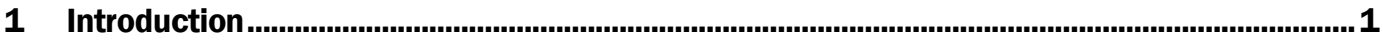

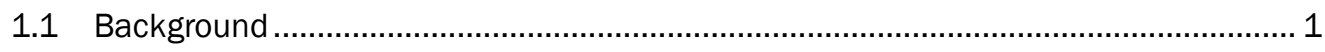

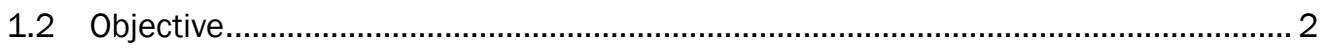

1.1 Scope

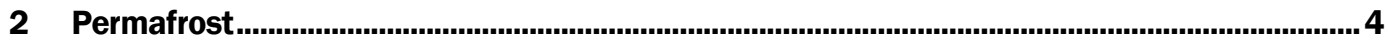

2.1 Challenges with permafrost identification ………................................................. 4

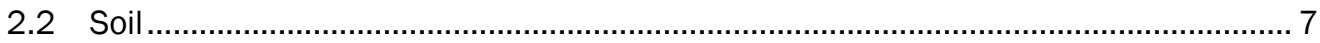

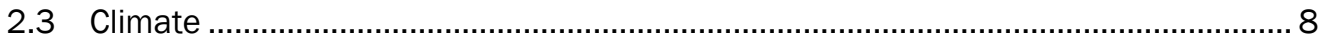

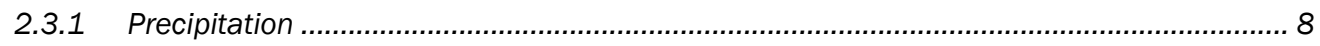

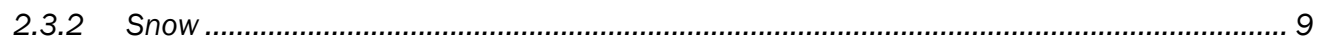

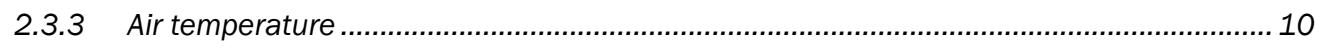

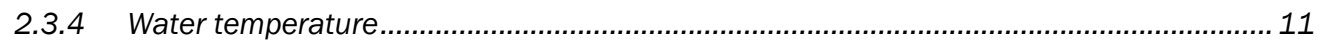

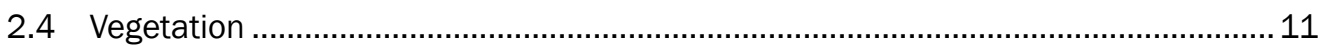

2.5 Landscape characteristics ....................................................................... 13

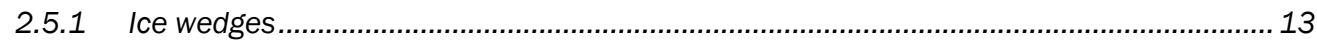

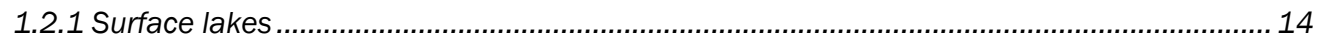

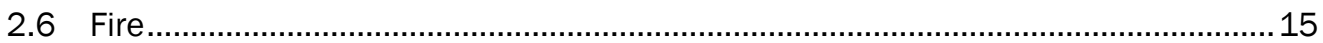

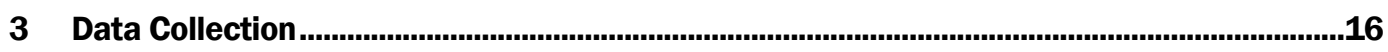

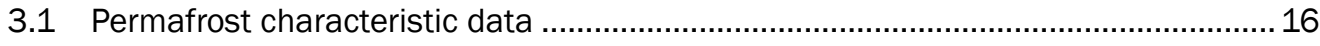

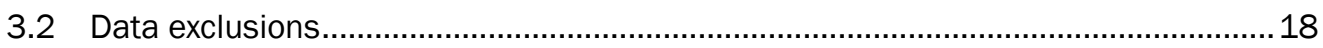

3.3 Pavement crack data................................................................................. 18

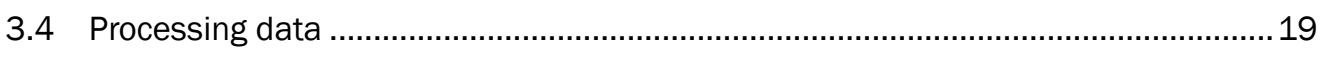

4 Modeling Pavement Cracks.............................................................................................22

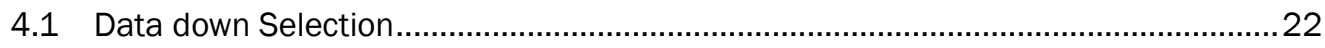

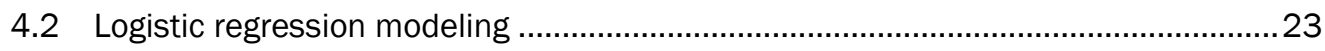

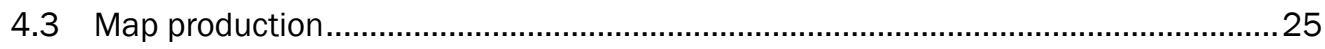

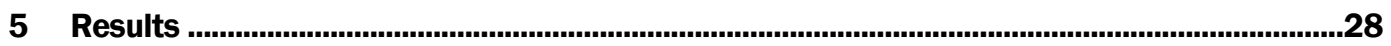

5.1 Limitations

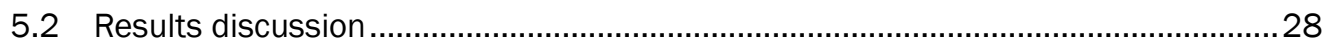

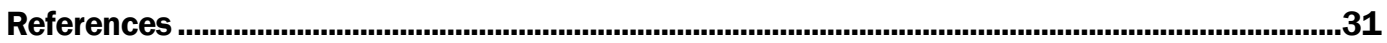

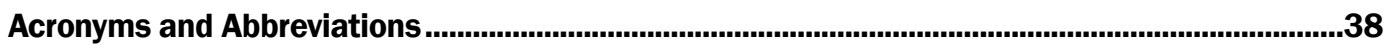

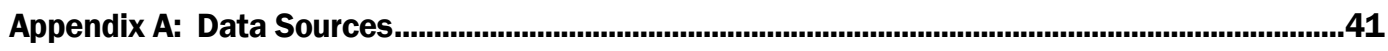

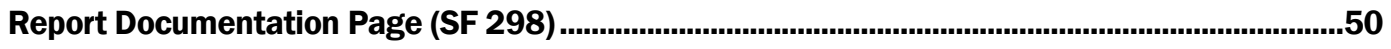




\section{Figures and Tables}

\section{Figures}

1 A graphic from the 2014 National Climate Assessment illustrates some of the expenses resulting from permafrost thaw as well as the hazards from thawing permafrost.

2 Graphic demonstrating road marks left on permafrost and the degradation at Storkerson Point, AK ............................................................................ 2

3 Study area. Data had to cover the entirety of the study area to be included ..................... 3

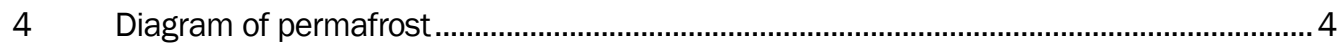

5 Distribution of continuous and discontinuous permafrost in the northern hemisphere. 5

6 Photograph from 1985 of pingos, which are formed by water that is pushed upwards from the pressure of ice........................................................................... 9

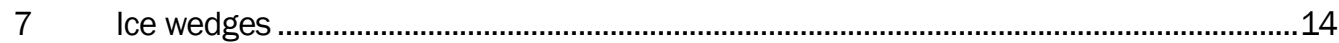

8 The distribution of crack lengths in the 2015 pavement dataset..................................19

9 New raster created by calculating the distance from urban areas ...................................25

10 Screen shot of the final data processing tool developed using ArcGIS pro. This tool enabled the rapid processing of input variable data ............................................26

11 Illustration of the output of multiplying slope by the variable coefficient from the statistical analysis..............................................................................................2

12 Mapped results of the probability of roads cracking in Alaska.........................................30

13 Map illustrating air temperature data from SnowData mapped in relationship to the areas of high probability of cracking (purple boxes)...........................30

\section{Tables}

1 Summary of climate factors and their impact on permafrost development ...................11

2 Summary of vegetation factors and their impacts on permafrost...................................13

3 Surface topography effects on permafrost ...................................................................13

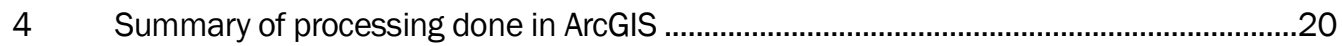

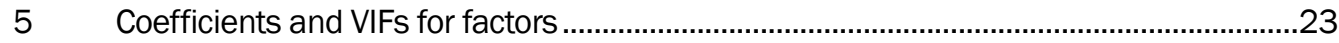

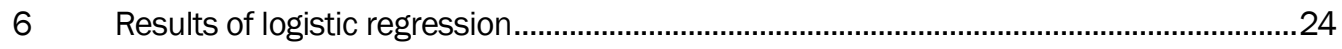

$7 \quad$ Classification resulting from the logistic regression.........................................................29 


\section{Preface}

This study was conducted for Office of the Assistant Secretary of the Army for Acquisition, Logistics, and Technology, ASA(ALT) under Program Element 622720896, "Base Facility Environmental Quality," Work Package "Infrastructure Planning in an Arctic Domain: Mitigating the Effects of Permafrost Thaw." The technical monitor was Alan B. Anderson, CEERD-CZT.

The work was performed by the Energy Branch (CFE) and the Ecological Processes Branch (CNN) of the Installations Division (CN), Construction Engineering Research Laboratory (ERDC-CERL). At the time of publication, Giselle Rodriguez was Chief, CEERD-CFE and Dr. Chris Rewerts was Chief, CEERD-CNN; Donald Hicks was Chief, CEERD-CN and CEERDCF; and Alan Anderson was Technical Director, CEERD-CZT. The Interim Deputy Director of ERDC-CERL was Michelle Hanson and the Interim Director was Dr. Kirankumar V. Topudurti.

COL Bryan S. Green was Commander of ERDC, and Dr. David W. Pittman was the Director. 
THIS PAGE INTENTIONALLY LEFT BLANK 


\section{Introduction}

\subsection{Background}

Permafrost is rock, soil, or sediment that stays below $0{ }^{\circ} \mathrm{C}$ for at least 2 consecutive years. About a quarter of the northern hemisphere's land mass is permafrost, and Alaska may be $85 \%$ permafrost. However, due to many factors, permafrost is degrading. In areas near Alaska's coast, for example, permafrost has warmed 6 to $8{ }^{\circ} \mathrm{F}$ at a 3.3 -ft depth since the mid-1980s (Romanovsky et al. 2008).

Degradation of permafrost represents a significant concern for the U.S. Army because permafrost thaw results in substantial changes in the geoecological system. To maintain an active fighting force into the future, the U.S. Army depends on its ability to train solders across a variety of environments, including areas characterized by permafrost. At installations in the Artic, permafrost degradation may compromise training activities and increase annual operations and maintenance (O\&M) costs. For example, the National Climate Assessment (NCADAC 2014) estimates that uneven thaw over the next 20 years in Alaska will add $\$ 3.6$ to $\$ 6.1$ billion (10$20 \%$ ) to the current costs of road, pipeline, and airport maintenance (Larsen et al. 2008). The melting of ground ice can cause the development of thermokarst lakes, which can lead to subsidence (Figure 1). Even some routine activities can further contribute to irreparable damage to permafrost. Figure 2 shows an area in Storkerson Point, AK where a driven vehicle compacted soil (left) such that 5 years later (right), the resulting thermokarst depression disturbed the tundra so that water now collects in the ruts (Dublin et al. 2001, p 25).

Because permafrost is a subsurface phenomenon, it is difficult to know where permafrost is located, and whether its degradation will impact infrastructure built on a given location. Moreover, as temperature increases continue to degrade permafrost, the ability to estimate the location of permafrost and its impacts on infrastructure will become increasingly important to avoid future increases in O\&M costs associated with permafrost degradation. This work was undertaken to outline a methodology to predict the probability that damage will occur to local infrastructure based on the probability that the infrastructure was built on permafrost. 
Figure 1. A graphic from the 2014 National Climate Assessment illustrates some of the expenses resulting from permafrost thaw as well as the hazards from thawing permafrost.

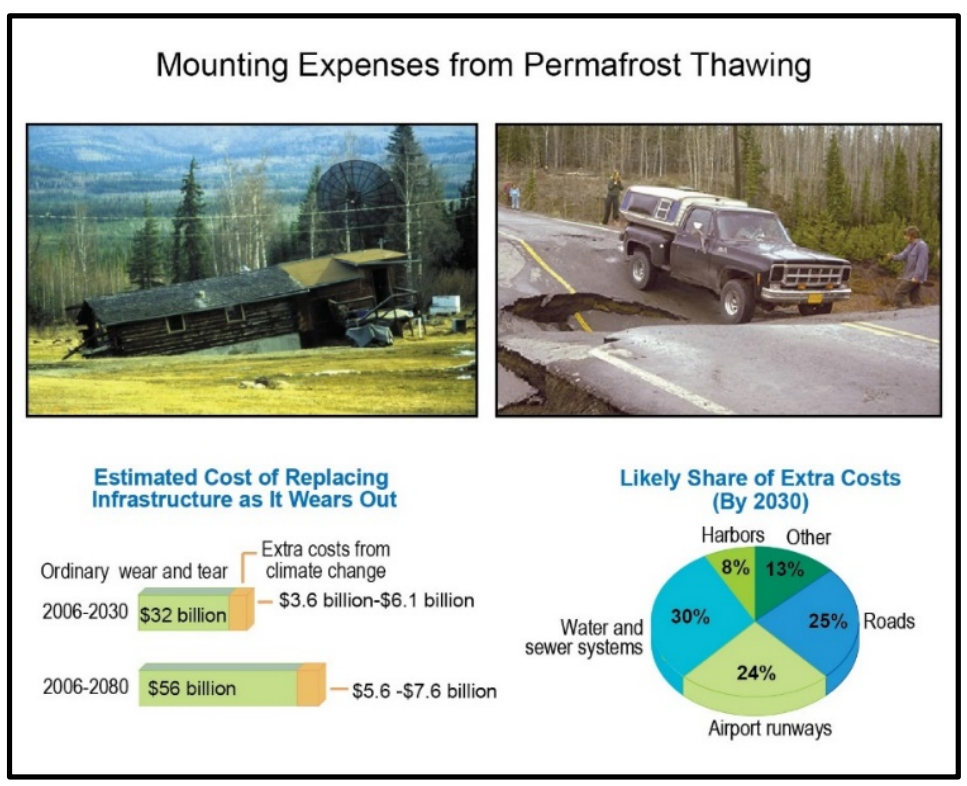

Figure 2. Graphic demonstrating road marks left on permafrost and the degradation at Storkerson Point, AK.

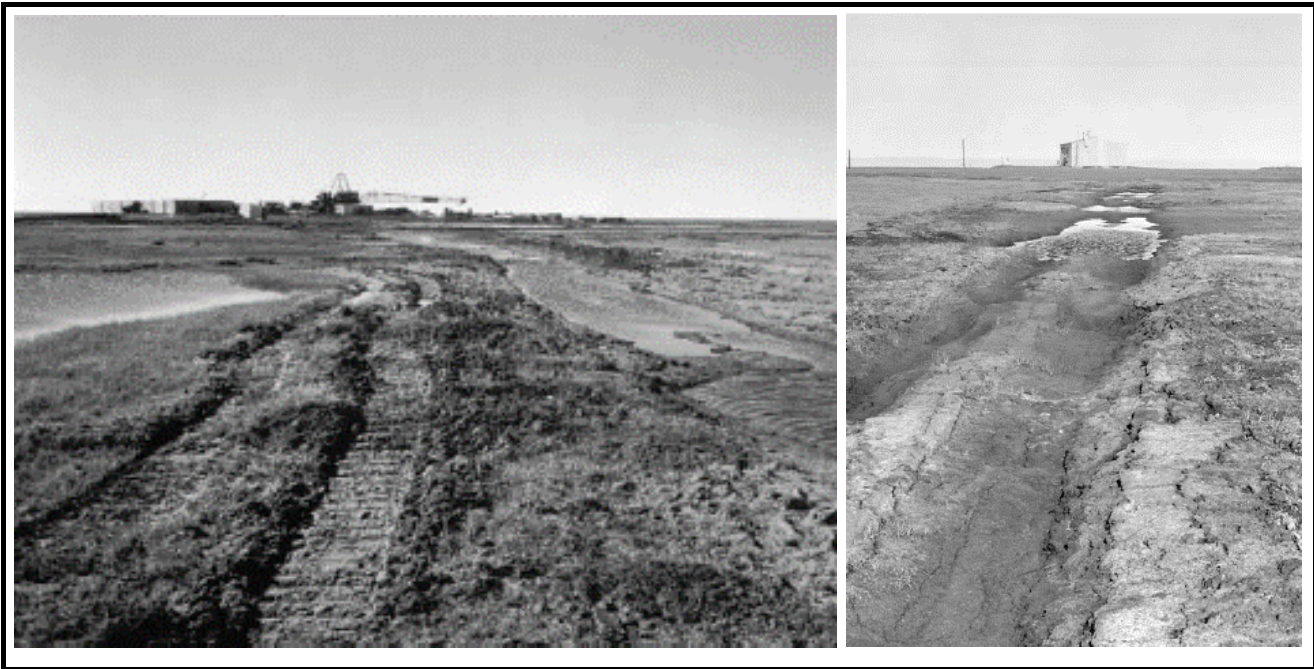

Source: Dublin et al. 2001, 25

\subsection{Objective}

The objective of this work was to outline a methodology to predict the probability that local infrastructure will incur damage (i.e., if a road will crack) based on the probability that the infrastructure was built on a permafrost location. 


\subsection{Scope}

This assessment was based on data pertaining to a study area that includes most of Alaska, including the cities of Fairbanks, Nome, Barrow, and Kotzebue; and the following U.S. Department of Defense (DoD) installations: Fort Wainwright, Eielson Air Force Base, and Donnelley Training Area (Figure 3). It is anticipated that the methodology outlined in this report may be expanded and adapted to other areas where permafrost occurs.

Figure 3. Study area. Data had to cover the entirety of the study area to be included.

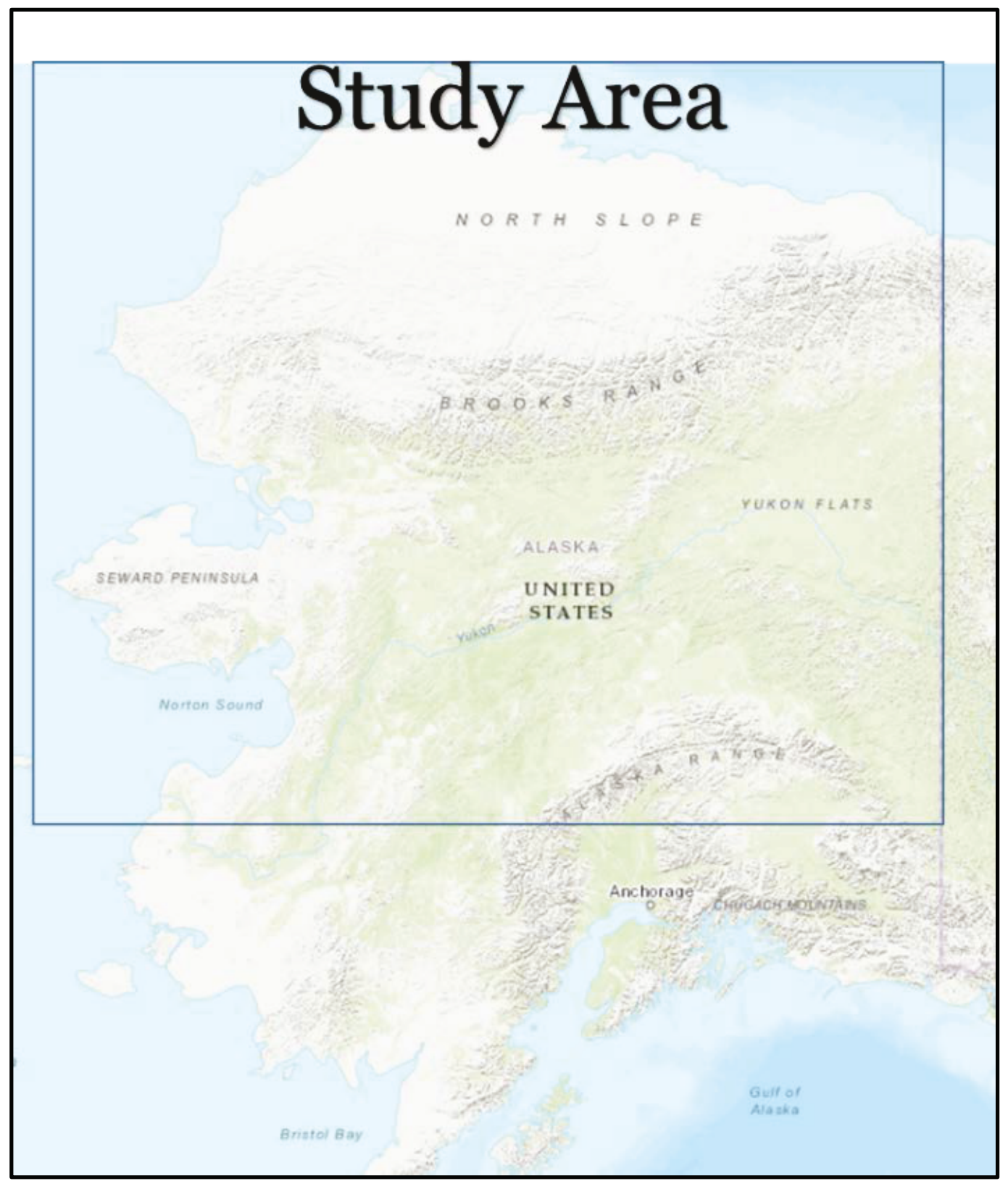




\section{Permafrost}

Permafrost is rock or soil that stays below $2{ }^{\circ} \mathrm{C}$ for 2 or more years. Permafrost often does not exist in areas with ground ice, but instead exists under a top soil layer that freezes and thaws annually called the "active layer." The active layer thickness (ALT) varies by season, longitude, and moisture content. It can be less than $1 \mathrm{ft}$ in wet, organic sediment to several feet in well-drained soil (Péwé 2018). Interspersed and below the permafrost layer are pockets of unfrozen soil called "taliks" (the bottom brown layer shown in Figure 4). Because the active layer insulates the permafrost, the ALT impacts the preservation of permafrost. Factors that cause the ALT to deepen often result in permafrost degradation.

Figure 4. Diagram of permafrost.

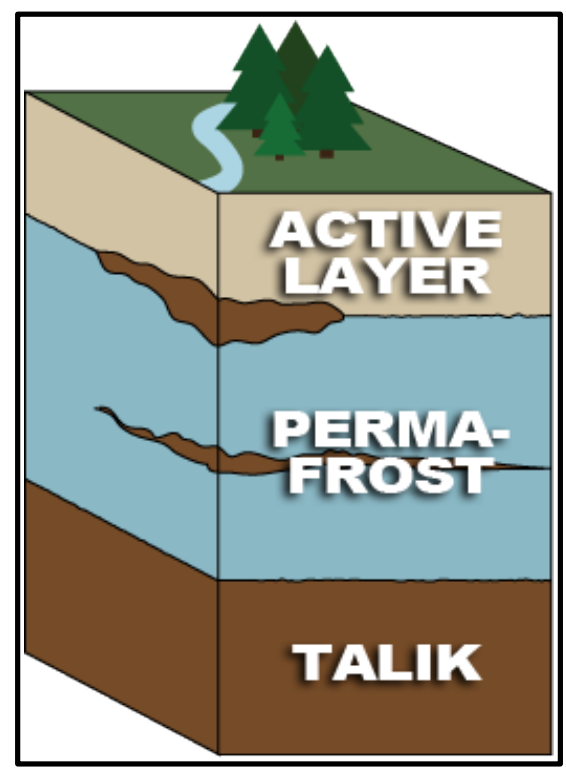

Source: Weather Underground (2018).

\subsection{Challenges with permafrost Identification}

Permafrost can be classified by its lateral continuity into two broad categories: continuous and discontinuous. In the continuous areas of the Artic and northwest Alaska, permafrost is ubiquitous. It covers almost all the landscape except for under lakes and rivers that do not freeze solid in the winter. Discontinuous permafrost, on the other hand, includes patches of frost-free area that gradually increase in size as one travels south until near the per- 
mafrost southern boundary, there are only small patches of permafrost. Figure 5 shows the distribution of continuous and discontinuous permafrost in the northern hemisphere. Note the change from continuous permafrost to discontinuous permafrost as one moves south. In areas with discontinuous permafrost, it can be challenging to identify permafrost locations.

Figure 5. Distribution of continuous and discontinuous permafrost in the northern hemisphere.

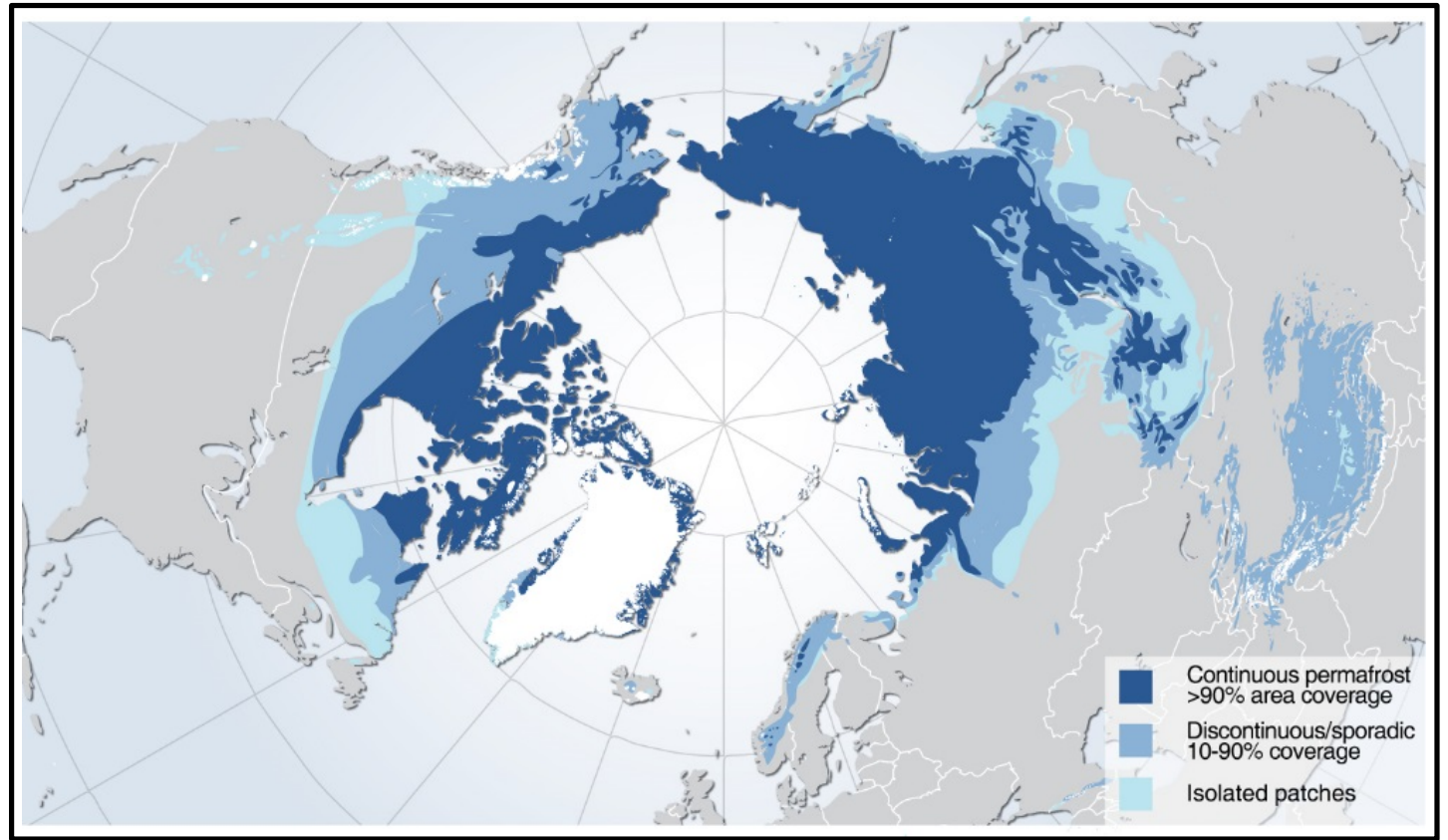

On this map, darker shades of purple indicate larger percentages of permanently frozen ground. Lighter purples, and the terms isolated and sporadic, refer to lower percentages of frozen ground.

Source: Map by Philippe Rekacewicz, UNEP/GRID-Arendal; data from International Permafrost Association, 1998. Circumpolar Active-Layer Permafrost System (CAPS), version 1.0.*

There are few landscape-scale assessments of permafrost locations in large part because permafrost is a subsurface condition. Most recent studies have focused on estimations and probabilistic modeling of permafrost location. For example the National Snow and Ice Data Center estimates discontinuous, sporadic, or isolated permafrost boundaries (Figure 5) (Brown et al. 2001).

There is a lack of more extensive maps because field research on permafrost is currently an expensive undertaking. Permafrost occurs in remote regions characterized by harsh climates, where research entails expensive logistics requiring air support. Moreover, there are currently few continuous datasets to support permafrost research (Groose 2015).

\footnotetext{
* United Nations Environment Programme (UNEP); Global Resource Information Database (GRID)
} 
However, increases in computing ability have enabled scientists to apply machine learning techniques to estimate the locations of permafrost. Pastick (2015) provided a 30m resolution estimation of "near-surface" permafrost (those areas where it is within $1 \mathrm{~m}$ of the surface), and an accompanying dataset. The dataset was developed through decision and regression tree approaches that statistically and spatially extend field observations using remotely sensed imagery, climatic data, and thematic maps of a wide range of surface and subsurface biophysical characteristics. The resultant data have global accuracy of $85 \%$ with lower accuracy at smaller scales. This dataset provides a fundamental starting point for future estimations of permafrost locations.

Olefeldt et al. (2016) performed another large scale estimation of permafrost location in northern circumpolar zones containing wetland, lakes, and thermokarst landscapes. The resulting dataset provides an areal estimate of permafrost locations in 2015. However, one of the limitations of the data is that they do not have consistent resolutions and they do not include all features. Similarly, Pastick et al. (2013) and Mishra and Riley (2012), respectively, applied machine learning to the estimation of active layer thickness for central Alaska, and to the organic-layer thickness across Alaska.

There is currently a push within the Artic Community to better understand the co-dependent ecological characteristics that can assist with the identification of permafrost. A 2014 National Research Council focused on the remote assessment of permafrost. Their report states that "there are considerably more permafrost related ecological properties that can be observed with remote sensing methods than permafrost processes and properties" (NRC 2015, p 12). Through the course of their meeting they identified over 60 ecological features associated with permafrost. Many of these characteristics are difficult to map at the scale necessary for this project with the tools available. Below is a list of identified features:

- Active layer thickness

- Ground ice (volume and morphology)

- Snow characteristics (extent, water equivalent, depth,

- density, conductivity)

- Surface topography (static, macro-, and micro-)

- Longer-term surface subsidence

- Thermokarst distribution

- Surface water bodies (including dynamics, redistribution) 
- Surficial geology-terrain units (including lithology, bedrock)

- Soil organic layer (thickness, moisture, conductivity)

- Land cover (including spectral vegetation indices)

- Vegetation structure and composition

- Methane (flux or concentration)

- Water vapor flux

- Carbon dioxide (flux or concentration)

- Land surface (skin) temperature

- Subsurface soil temperature

- Seasonal heave/subsidence

- Soil moisture

- Biomass (above ground).

These studies do not model ecological characteristics that exist alongside permafrost in nature, and that signal its potential degradation. For the purposes of the U.S. Army (infrastructure placement and planning), it is crucial to identify factors that lead to permafrost degradation and locations that are more likely to degrade. This research is working to fill that void by producing a scientific product that U.S. Army Range managers can use to identify areas that are more likely to degrade. To that end, this work further focused its literature review to answer three questions:

1. What are the landscape characteristics that are often indicators of the existence of permafrost?

2. What methods are used to measure those permafrost characteristics?

3. What are the characteristics that lead permafrost to change state?

\subsection{Soil}

Soil characteristics are strongly correlated with permafrost. Factors that are related to the soil organic layer (a layer of plant residues in relatively undecomposed form) and that are important to characterizing permafrost, are: thickness, moisture content, density, and texture. These factors relate to permafrost heave, thaw segmentation, and to its moisture-holding abilities (Farouki 1981).

The composition of the soil type can affect the ALT, which can range from less than $1 \mathrm{ft}$ in wet organic sediment to several feet in well-drained soil (Péwé 2018). However, there is currently a research gap on how deepening of the active layer will occur on the landscape scale (NRC 2015). 
Soil moisture is a significant factor in the surface energy balance, and a major factor in permafrost aggradation and degradation because of the thermal properties of water and ice (NRC 2015). Permafrost exerts a strong control on soil hydrologic conditions, since it acts as a barrier to vertical water flow and thereby supports perched water tables and saturated or near-saturated soils in the active layer. Isolated studies (Walvoord and Striegl 2007, Muskett and Romanovsky 2009) have demonstrated that increases in groundwater contributions to river base-flow have been attributed to permafrost. Precipitation has been demonstrated to be one of the key drivers in permafrost degradation (Lawrence et al. 2015). Conversely, reductions in soil moisture can increase precipitation as moisture transfers to the atmosphere. Additionally, soil moisture information is required to estimate the thermal properties of the ground required for permafrost modeling.

However, measuring soil moisture remotely requires sophisticated equipment. Synthetic Aperture Radar (SAR) instruments at the L-band and higher are suited for the estimation of soil and surface moisture to about 5 $\mathrm{cm}$. SAR operating at the P-bands and below can penetrate to the $10 \mathrm{Os}$ of centimeters to a meter. However, there are currently no P-band SAR in space, and the higher band SARs have only been used infrequently for soil moisture retrieval. This is a data acquisition issue. The National Aeronautics and Space Administration's (NASA's) Soil Moisture Active/ Passive (SMAP), which was launched at the end of 2015, is a combined radar-radiometer instrument with the goal of mapping soil moisture, including permafrost. The lowest resolution for SMAP products is $3 \mathrm{~km}$ (NSIDC 2017).

\subsection{Climate}

Climate is a key driver for the evolution of frozen landscapes. In the past, changes in climate have led to the creation of permafrost. More recently, changes are leading to its degradation.

\subsubsection{Precipitation}

While rates of precipitation on the Alaskan tundra is similar to that of deserts, precipitation is a source of moisture that is a driver for the evolution of permafrost and ground ice. Since water cannot penetrate permafrost, the active layer becomes saturated with water, resulting in wetlands or landscape features like pingos (Figure 6). Additional precipitation can damage the landscape. Flood events can wash away the top active layer, 
thereby reducing the distance to the permafrost. Rainfall can cause this active layer to degrade or melt, which then affects the permafrost (Oht 2003). Moreover, the addition of liquid water when soil temperatures are between -6 and $0{ }^{\circ} \mathrm{C}$ significantly impacts soil temperatures as latent heat is released. Kokelj et al. (2015) analyzed LandSat Images from 1985-2011 in the Northwest Territory of Canada and found an increase in thaw slumps, which are slope failures resulting from thawing of ice-rich permafrost resulting from higher rainfall. They found that higher rainfall could intensify the slump activity and increase the slope-sediment cascade.

Figure 6. Photograph from 1985 of pingos, which are formed by water that is pushed upwards from the pressure of ice.

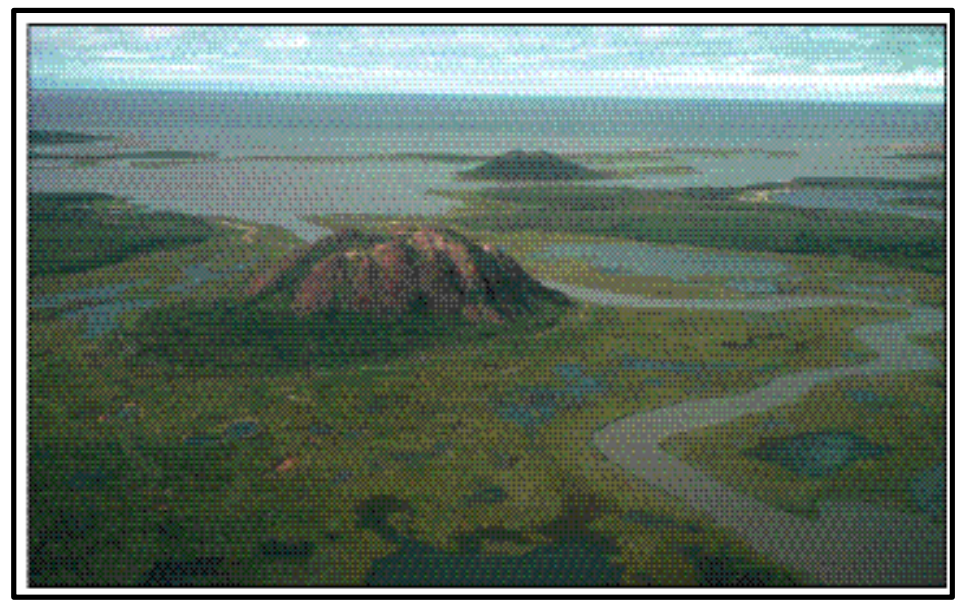

Source: Miller and Whitehead (1999).

There are a variety of ways to measure precipitation. Research summarized by the National Research Council (2014) found that there is a preference towards Quantitative Perception Estimates (QPEs). QPEs, which are generated by meteorological satellites, measure how much precipitation falls. QPE measurements work best for the contiguous United States and areas with precipitation that is solid or mixed. The newly (2014) launched Global Precipitation Mission by NASA is collecting precipitation data globally, including artic areas. Currently precipitation estimates are available for $5 \mathrm{~km}$ grids (NASA 2017).

\subsubsection{Snow}

Another important characteristic for the evolution of permafrost is snow because of its insulating properties-however these properties can have varying results on the formation and survival of permafrost. As the winter 
progresses and air temperature decreases while snow thicknesses increase with additional accumulation, snow beings to act as an insulator (Zhang 2005). In areas of continuous permafrost, seasonal snow cover can increase the mean annual ground and permafrost temperatures by several degrees (Zhang 2005). Autumn snowfall, because of its high albedo and solar elevation, has a cooling effect on the ground when the snow cover is relatively thin and air temperatures are around $0{ }^{\circ} \mathrm{C}$. In particular, when snow depth increased in autumn rather than winter permafrost was more likely to degrade than if the snow fall occurred later. This is because the soil was not able to release as much heat before being insulated by the snow (Park et al. 2015). However, other research has found that in areas of discontinuous or sporadic permafrost, the absence of snow cover can contribute to permafrost formation (Tingjun Zhang 2005).

Studies in northern Quebec, Canada since the late 1950s have demonstrated a link between snow-fall and permafrost development (Zhang 2005). They found that deep snow cover prevents the development of permafrost even if the mean annual temperature is $-4{ }^{\circ} \mathrm{C}$. Other studies have demonstrated that discontinuous permafrost may develop if the snow depth is under 70 to $75 \mathrm{~cm}$. For northern regions, researchers have had to rely on mapping snow-cover. Sensors with optical bands (like MODIS [Moderate Resolution Imaging Spectroradiometer]) can successfully map snow-covered areas at the 500-m pixel particularly in tree-less areas (Hall and Riggs 2007). However, because of the lack of landscape scale information on snow-depth is lacking. Seasonal totals on snow depth, density, data of first snow, and other factors are available for 1979-2012 as part of the SnowData project (LCC 2017). The SnowData project is the result of simulation modeling.

\subsubsection{Air temperature}

Air temperature and snow pack have been demonstrated in multiple studies to be the greatest climatic factors with an impact on permafrost thaw. Air temperature and warming trends have an impact on permafrost by causing soil temperatures to rise, resulting in an increase in the active layer thickness (Zhang and Stamnes 1998). The greatest initial impact of air temperature increases is on discontinuous permafrost. Discontinuous permafrost has a mean annual surface temperature that is typically warmer than $-5{ }^{\circ} \mathrm{C}$; in some parts of the Seward Peninsula this is $-2{ }^{\circ} \mathrm{C}$. Be- 
cause of this higher temperature, discontinuous permafrost is more vulnerable to warming (Osterkamp 2005). Zhang and Stamnes (1998) demonstrated that changes in air temperature in Barrow, AK have a greater impact on permafrost temperature than seasonal snow cover.

\subsubsection{Water temperature}

Temperatures of water in lakes influences the development of taliks, thermal erosion, and can lead to surface permafrost degradation (Arp et al. 2010). New research is additionally showing how increases in water temperatures can increase the soil temperature surrounding the lake leading to permafrosts thaw (Lawrence et al. 2015). Thermal sensors record the surface temperature for water features. Satellites like MODIS and AVHRR capture only the surface temperatures of the largest features, as they have a spatial resolution of $\sim 1 \mathrm{~km}$, but capture data twice or more a day. While Landsat and ASTER have a better resolution of $\sim 100$, they have reduced sampling to about once a week. Assessing seasonal changes in water temperatures. The changes in the temperature of the water can result in the surface permafrost melting.

Table 1. Summary of climate factors and their impact on permafrost development.

\begin{tabular}{|l|l|l|}
\hline \multicolumn{1}{|c|}{ Factor } & \multicolumn{1}{|c|}{ Negative Impact on Permafrost } & Positive Impact on Permafrost \\
\hline Snow & $\begin{array}{l}\text { Early HEAVY snow pack (Park et al. 2015) } \\
\text { Deep snow-cover insulates the ground too } \\
\text { much (over 75 cm) }\end{array}$ & $\begin{array}{l}\text { Light Autumn Snowfall (allows } \\
\text { the ground to cool) }\end{array}$ \\
\hline Precipitation & $\begin{array}{l}\text { Higher rainfall levels can result in } \\
\text { permafrost thaw (particularly if it is on } \\
\text { slopes) (Kokelj et al. 2015). } \\
\text { Melts/ degrades the active layer (Oht } \\
\text { 2003) }\end{array}$ & \\
\hline Air Temperature & $\begin{array}{l}\text { causing soil temperatures to rise, resulting } \\
\text { in an increase in the active layer thickness } \\
\text { (Zhang and Stamnes 1998) }\end{array}$ & \\
\hline $\begin{array}{l}\text { Water } \\
\text { Temperature }\end{array}$ & $\begin{array}{l}\text { Increased temperature leads to increased } \\
\text { soil temperature and permafrost thaw } \\
\text { (Lawrence et al. 2015). }\end{array}$ & \\
\hline
\end{tabular}

\subsection{Vegetation}

Almost all of the soils biological activity takes place in the active layer during the summer (Kelley, Epstein, and Walker 2004). While any factors (precipitation, soil type, temperature) impact the depth of the active layer 
thaw, vegetation does have a strong impact. The surface vegetation can intercept incoming solar radiation and thereby insulate the soil. A latitudinal temperature gradient study in Alaska and Canada found that there is an interaction between temperature and vegetation to control the active layer thickness thaw. Using the Normalized Difference Vegetation Index (NDVI) as an indicator of vegetation, the researchers combined variables of temperature, active layer depth, and NDVI (vegetation). Their study found shallow thaw depths in areas two areas: (1) warmer temperatures but higher vegetation levels, and (2) colder areas with lower vegetation levels. The latter is because bare ground has less insulation abilities. The greatest thaw depth was seen in areas with moderate air temperature and moderate vegetation (Kelley, Epstein, and Walker 2004).

Researchers studying permafrost degradation in Northeast China used multiple years of LandSat imagery to map vegetation. The study found reductions in "greenness" (vegetation) to be linked to permafrost degradation (Guo et al. 2017). An additional study connected in boreal forests of Northwest Canada found a relationship between leaf area thickens and shallower ALT. While the reasons behind this are not fully known, the limited thaw is believed to be a result of the protection provided by the canopy (Fischer 2014).

Additionally, there are relationships between the necessary soil characteristics for vegetation to thrive and permafrost. White spruce, cottonwood, birch, and certain willows will live where there is approximately $4 \mathrm{ft}$ of soil above the permafrost (Lawrence et al. 2015). Through an Ecological Land Survey approach, researches characterized the Donnelley Training Area and found some relationships between vegetation and permafrost (Jorgenson et al. 2001):

- White Spruce occurred on well-drained upland sites that lack permafrost. The white spruce was also present on waterlogged and dry, sunny slopes.

- Paperbirch grows best in soil free from shallow permafrost (Safford and Bjorkbom 1975). However, paperbirch saplings have been found to be in areas underlain with discontinuous permafrost and shallow thaw permafrost.

- The Black Spruce dominated areas in the study where there was near surface permafrost. Black spruce tend to have a permafrost thaw depth of 8-35 inches (Fryer 2014). 
Table 2. Summary of vegetation factors and their impacts on permafrost

\begin{tabular}{|l|l|l|}
\hline Factor & Negative Impact on Permafrost & Positive Impact on Permafrost \\
\hline NDVI & $\begin{array}{l}\text { The greatest thaw depth was seen in } \\
\text { areas with moderate air temperature } \\
\text { and moderate vegetation (Kelley, } \\
\text { Epstein, and Walker 2004). } \\
\text { Reduction in vegetation (greenness) } \\
\text { linked to permafrost degradation (Guo } \\
\text { et al. 2017) }\end{array}$ & $\begin{array}{l}\text { Their study found shallow thaw } \\
\text { depths in areas two areas-1) } \\
\text { warmer temperatures but higher } \\
\text { vegetation levels 2) colder areas } \\
\text { with lower vegetation levels (Kelley, } \\
\text { Epstein, and Walker 2004). }\end{array}$ \\
\hline $\begin{array}{l}\text { Leaf Area } \\
\text { Thickness }\end{array}$ & & $\begin{array}{l}\text { Shallower ALT (thereby limiting } \\
\text { thaw) linked to higher leaf area } \\
\text { index (Fischer 2014). }\end{array}$ \\
\hline Trees & White Spruce: White spruce occurs in \\
well & $\begin{array}{l}\text { Commonly, landscapes underlain by } \\
\text { permafrost support open dwarf } \\
\text { spruce forest or woodland and the } \\
\text { trees are tipped in various } \\
\text { directions as a result of frost heave. }\end{array}$ \\
\hline
\end{tabular}

\subsection{Landscape characteristics}

Surface topography affects permafrost (Table 3). South-facing slopes receive more incoming solar radiation than other slopes (particularly northern). As a result, the permafrost is generally thinner on south-facing slopes in areas with continuous permafrost and absent in discontinuous zones (Cote 2002). With high resolution historic surface elevation data, one can identify elevation changes that may signify areas where active thermokarst is occurring (Jones et al. 2012). Light Detection and Ranging (LiDAR) provides data on elevation in addition to information on vegetation canopies. The high resolution of the produced datasets can be used in change detection.

Table 3. Surface topography effects on permafrost.

\begin{tabular}{|l|l|l|}
\hline Factor & Negative Impact on Permafrost & Positive Impact on Permafrost \\
\hline North-facing slopes & $\begin{array}{l}\text { Permafrost is more likely to occur on } \\
\text { a north-facing slope. (Viereck, Van } \\
\text { Cleve, and Dyrness 1986; Williams } \\
1970) .\end{array}$ \\
\hline Valley Bottoms & $\begin{array}{l}\text { Permafrost is more likely to occur on } \\
\text { valley bottoms (Viereck, Van Cleve, } \\
\text { and Dyrness 1986; Williams 1970). }\end{array}$ \\
\hline
\end{tabular}

\subsubsection{Ice wedges}

Remote Sensing using non-earth based sensors is one mechanism to assess the presence/ absence of permafrost based on surface characteristics. Remote sensing alone cannot identify the extents of permafrost as it is a 
subsurface temperature phenomenon, so it may not be reflected on the surface. Ice-wedges can often be observed visually. Ice-wedges are formed over the timescale of centuries to millennia and are formed through snowmelt creating cracks in the ground through freeze-thaw cycles. These icewedges are generally 3-4 m wide and several meters deep (Liljedahl et al. 2016) and produce a surface of low-centered polygons (Figure 7). Icewedges have tremendous differential thaw potential as they account for about 20\% of the uppermost permafrost volume (Kanevskiy et al. 2013).

Figure 7. Ice wedges.

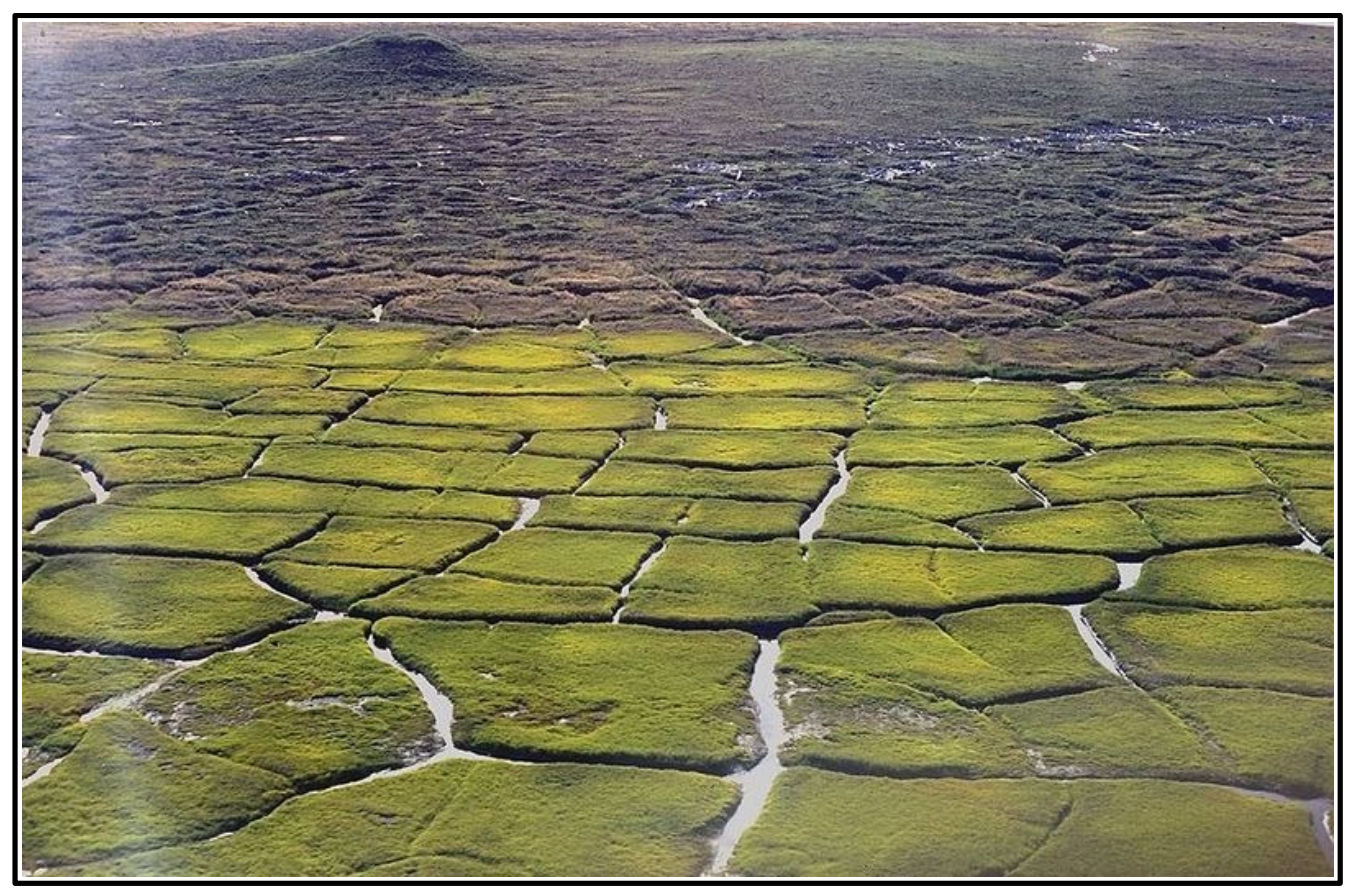

Source: Canadian Soil Information Service, in Wooster Geologists (2016).

\subsubsection{Surface lakes}

Thermokarst lakes and ponds, which form through the degradation of permafrost, are indicators of permafrost. Grosse (2015) indicates that these lakes have an impact on the hydrology, geomorphology, and chemical cycling in the permafrost lowlands. LandSat imagery $(\sim 15-80 \mathrm{~m})$ have been used to identify changes in thermokarst features; however due to the scale of the pixel cells this is not suitable for shore erosion studies. High-resolution satellite imagery (WorldView, QuickBird etc.) are commonly used for assessing local and regional changes in thermokarst lakes including appearance and disappearance. The Surface Water Ocean Topography 
(SWOT) satellite to be launched in 2020 will be able to identify lakes as small as $250 \mathrm{~m} 2$ and get water elevation with an accuracy of $10 \mathrm{~cm}$.

\subsection{Fire}

Fire presents a significant disturbance on the permafrost landscape, as it affects the recovery patterns and the depth of the organic layers. In a study of permafrost in central Alaska, researchers found that fires caused a fivefold decrease in the mean surface organic thickness, a doubling of water storage in the active layer, a doubling of thaw depth, and in increase in soil temperature at the surface. Fires led to degradation the upper permafrost layers at all burn sites, but the soil textures at some sites allowed lower permafrost to persist (Nossov et al. 2013). Devastating artic fires caused by lightning are increasing, rising about $2-5 \%$ annually for the past four decades. These lightning induced fires are a result of increasing thunderstorm frequency, which is encouraged by warmer temperatures (Veraverbeke et al. 2017). Furthermore a study of lightning Continental United States (CONUS) estimates that with each degree of Celsius that global temperatures rise, CONUS lightning strikes are predicted to increase $12 \pm 5 \%$ (Romps et al. 2014). As tree cover moves northward the damage from the trend and impact on permafrost could continue (Waldman 2017). Landsat 8 provides the necessary resolution, coverage, and frequency to assess the relationships between permafrost stability and fire disturbances. For known fires, the Bureau of Land Management (BLM) provides polygons of the fire perimeters (AICC 2016b). 


\section{Data Collection}

Using the literature review as a basis for future work, the process of collecting spatially explicit data for the factors outlined above was begun. This process was used to develop a list data sources and factors that relate to permafrost degradation (included in Appendix A). Not all of the identified factors could be used in the analysis outlined in this report. To narrow down the factors, the following criteria were applied:

1. Data must be at a resolution of at least $2 \mathrm{~km}$, but preferably at a lower resolution.

2. Data must be produced by a government agency as an authoritative dataset, or have a strong peer-review backing.

3. Data must be easily downloaded using a web interface or via file transfer protocol (FTP).

4. Data must be available in a format that could easily be imported into ArcMap Geographic Information System (GIS) software.

5. Data must have been taken within the study area (Figure 3, p 3), which was selected because it represented an area with exceptional data coverage, was large enough to provide a meaningful statistical analysis, and included areas of both continuous and discontinuous permafrost.

\subsection{Permafrost characteristic data}

The literature review confirmed that it is nearly impossible to identify permafrost from remote data. Consequently, data were collected from a variety of locations that can be indicators of the presence of permafrost, or that are signals of possible permafrost degradation.

Elevation: The National Geospatial Intelligence Agency's (NGA's) Digital Terrain Elevation Data (DTED) product, which is a 3om digital elevation model (DEM), was used to produce three further products using the desktop GIS software ArcGIS: hillshade, slope, and aspect (NGA 2012).

\section{- Geology:}

- Soil albedo data were provided through the ArcGIS Online platform. These data were derived using the Natural Resources Conservation Service data by taking the component table field "Albedo Dry - Representative Value (albedodry_r).” (NRCS 2017). 
- As discussed in the literature review, locations of thermokarst sites are difficult to identify remotely. A 2014 Thermokarst estimation map produced by the U.S. Geological Survey (USGS) was used as a starting estimation point for thermokarst locations (Szukalski 2014).

- A permafrost probability map developed by the USGS was used as a mechanism of roughly estimating the location of permafrost (Pastick et al. 2015).

- Wetlands data from the National Wetlands Inventory were used to identify wetland areas and thus areas that may have thermokarst development (USFWS 2016).

- To better assess the impacts of lightning and fire on permafrost, data were obtained from the Alaska Interagency Coordination Center lightning (AICC) (1986) and from fire polygons (AICC 2016).

- Landcover data were obtained the National Land Cover database land cover classifications for the state of Alaska (MRLC 2014).

- Climate: Data produced by SnowData were used for the climate characteristics. Snowdata is a simulation of climate and snow information based on historical weather and climate information. It includes 21 data variables for each year between 1979 and 2012. Some of the variables measure similar characteristics. For example, the dataset includes "First Snow" calculated as the "day of the year" and "day of simulation." For ease within the statistical model, the day of simulation (dos) variables were used. Since data were available over many years, the values for the years 2008-2012 were selected and averaged so that possible anomalies in any one year would not overly impact the results of the study. SnowData (LCC 2017) provided the following variables: Air Temperature, Last Snow Day, Number of days with rain on snow, First Snow Day, Snow-free days, and Snow up to date.

- Human Impact: A factor that was not highlighted in the literature review, but that was deemed important for this study, was human impact. Because the objective of this work was to examine the probability of roads cracking, it seemed probable that areas with higher usage might be more likely to crack. Because road count data were unavailable, urban area outlines from the U.S. Census Bureau were used as a rough estimate of population centers and areas with higher populations (U.S. Census Bureau 2016). 


\subsection{Data exclusions}

Note that some factors that were identified in the literature review as being important characteristics were not included in the preceding list. There are many reasons for their exclusion, most commonly because of the difficulty in obtaining data. Factors excluded from this analysis were soils, soil moisture, and vegetation.

\subsection{Pavement crack data}

A model of the probability map of the likelihood that a road would crack was developed using existing road crack data from the Alaskan Department of Transportation (AKDOT). Using road cracking probability was a way to roughly estimate the impact of permafrost, even though these cracks can result from frost heave, expansion, and road use. The AKDOT (2016) dataset is produced annually for the Highway Performance Monitoring System (HPMS) and includes location, size of the crack, and roughness of the road. Data for the years 2005-2015 at various scales ranging from $1 / 100$ mile to 1 mile were obtained from AKDOT officials. For simplicity, this analysis dealt only with the 2015 data, which was at the $1 / 10$ th mile. These data were selected because they were temporally the newest, they had few missing values, and they conveyed data at a small scale. It was decided not to combine data from multiple years because it was not possible to know if there had been any road maintenance on a segment that could account for a cracks absence in later years. Furthermore, the road segments differed slightly from year to year in length and there was no clear identifier field that persisted through multiple years of data.

The 2015 dataset contained 32,607 road segments and attributes for each segment, including the length of road that was cracked and the percentage of the road segment that was cracked. This analysis used the attribute "HPMS_Cracking_Per," which is the percent of a segment that is cracked. This is a percentage of the wheelpath that has alligator/fatigue cracking in it. It is calculated by taking the square feet from the pattern cracking zones 2 and 5 and dividing it by the entire section area. ${ }^{*}$ Using the percentage of a segment that was cracked made it possible to account for differences in the road segment lengths, as road segment lengths ranged from $6 \mathrm{ft}$ to just over

* Pavey, Andrew. 2017. Letter to Juliana Wilhoit. Subject: Overall Pavement Data as Feature Layer? July 18, 2017. Champaign, IL: Engineer Research and Development Center, Construction Engineering Research Laboratory (ERDC-CERL). 
the designated road length at 0.11 miles. The average road length was 0.98 miles, which was slightly shorter than the designated road length. In addition to all of the possible attributes for road cracks, this characteristic had the fewest null values, which gave it the greatest use in this analysis. Figure 8 shows the distribution of crack lengths in the 2015 pavement dataset.

Figure 8. The distribution of crack lengths in the 2015 pavement dataset.

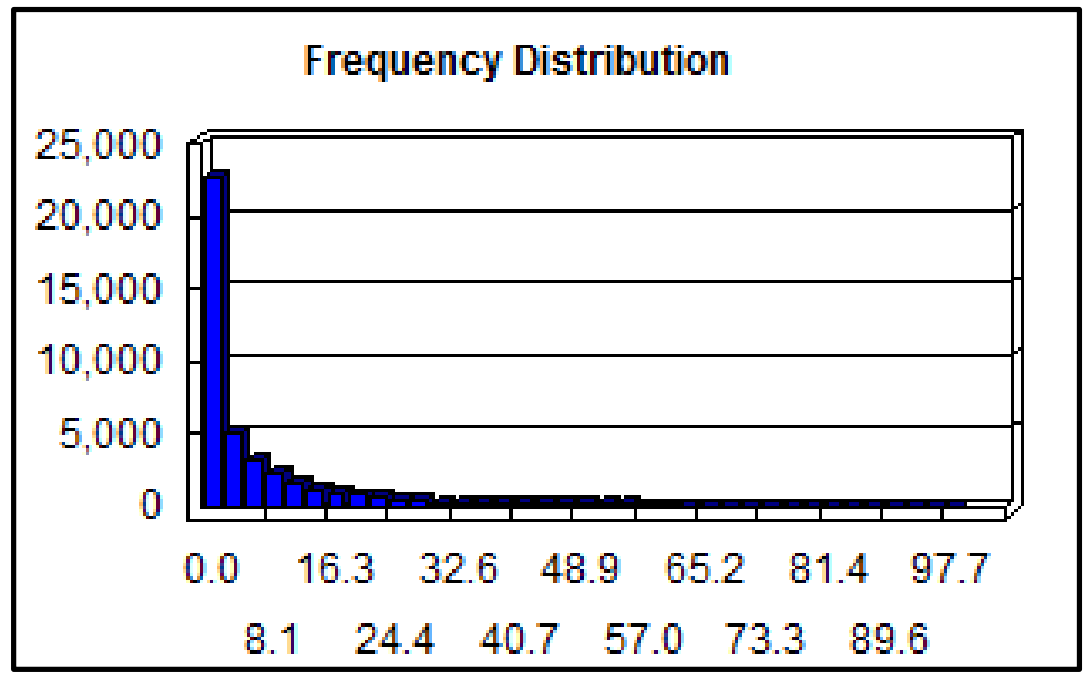

For the analysis of probability of roads cracking, the dependent variable was a binary coding of crack presence/absence. Segments were marked as having an absence of a crack if the crack coverage was less than $2 \%$. This value was a rough estimate used in an effort to exclude small cracks and to focus on larger cracks.

\subsection{Processing data}

The data sources collected (see Section 2.1, "Challenges with permafrost Identification," p. 4) were then opened in the desktop GIS software ArcGIS Pro. Each data layer was processed to summarize the particular input data to each road segment so that each segment would have a value as it related to each factor. Given the differences in spatial scale, the element that each factor was measuring, and the uniqueness of the data, the data were not summarized uniformly. Table 4 summarizes the completed processing. In general, the zonal statistics tool was used for continuous data while the 
near tool was used for feature data that were only present in certain locations. The processing relied on two tools within the ArcGIS software:

- Zonal Statistics: Zonal statistics provide a summary of the data that intersect or are contained within another layer (Esri 2014). For example, if one had parcel data for multiple neighborhoods within a city, it would be possible to use the zonal statistics tool to get a summary for the parcels within a neighborhood.

- Near: the Near tool provides a summary of the distance between one feature and another. For this research, the Near tool was used to determine the distance between each road segment and the applicable factor (Esri 2017).

Table 4. Summary of processing done in ArcGIS.

\begin{tabular}{|l|l|}
\hline Data & Notes \\
\hline Lightning & $\begin{array}{l}\text { The NEAR tool was used to calculate the distance to the nearest lightning } \\
\text { strike from 2008-2015. The near tool was used because there were only } \\
\text { three instances of reported lightning strikes on a roadway in Alaska, and } \\
\text { because it was determined that spatial fidelity of the data for its } \\
\text { precession in marking road strikes was not trustworthy. }\end{array}$ \\
\hline Wetlands & $\begin{array}{l}\text { Using the NEAR tool calculated the distance from each road segment to } \\
\text { wetlands. The near tool was used because it was known that permafrost } \\
\text { can degrade around the edges of water features as the temperatures } \\
\text { increase. }\end{array}$ \\
\hline Soil Albedo & $\begin{array}{l}\text { Used Zonal Statistics to summarize the average soil albedo per road } \\
\text { segment. Because the soil albedo was a layer that was present for the } \\
\text { entirety of the study area, It was possible to simply do the zonal statistics } \\
\text { to get a summary of albedo for the road segment. The average of the } \\
\text { albedo was taken over the segment. }\end{array}$ \\
\hline Fire & $\begin{array}{l}\text { The NEAR tool was used to calculate the distance to a fire from 2008- } \\
\text { 2015. Since fire is much like lightning, and because the spatial data was } \\
\text { considered untrustworthy, there was a desire to see the distance from } \\
\text { the road to a fire. It was assumed that areas that were close to a fire area } \\
\text { may have received some level of damage to both infrastructure and } \\
\text { permafrost. }\end{array}$ \\
\hline Land Cover & $\begin{array}{l}\text { The Landcover data are a continuous dataset for Alaska. However, } \\
\text { because of the manner that land cover data are processed, road } \\
\text { segments are often categorized as "developed." It was assumed that the } \\
\text { landcover surrounding the roads is indicative of the original landscape } \\
\text { state and that properties associated with landcover (e.g., soil type) would } \\
\text { be similar beneath the roads. To get an estimation of the surrounding } \\
\text { land cover for an area, a 120-ft buffer was added to the roads and } \\
\text { MAJORITY was used to get the most common land cover. }\end{array}$ \\
\hline
\end{tabular}




\begin{tabular}{|l|l|}
\hline Data & Notes \\
\hline Thermokarst & $\begin{array}{l}\text { The NEAR tool was used to calculate the distance from each road } \\
\text { segment to USGS identified thermokarst. The near tool was used here to } \\
\text { assess proximity to thermokarst. Locations that were closer were } \\
\text { presumed to being at a higher risk of degradation. }\end{array}$ \\
\hline $\begin{array}{l}\text { Permafrost } \\
\text { estimated depth }\end{array}$ & $\begin{array}{l}\text { These data were summarized using zonal statistics to obtain the mean } \\
\text { estimated depth to permafrost. }\end{array}$ \\
\hline $\begin{array}{l}\text { Permafrost } \\
\text { Presence Map }\end{array}$ & $\begin{array}{l}\text { These data were summarized using zonal statistics to obtain the mean } \\
\text { probability of the presence of permafrost. The original data had values of } \\
\text { probability from 5-105. Efforts were made to contact the studies' authors } \\
\text { for confirmation on the data, they did not respond. As a result the values } \\
\text { over 100 were resampled to be the values 1-5\%. }\end{array}$ \\
\hline slope & $\begin{array}{l}\text { Using an input DEM the slope was calculated in degrees. Then the } \\
\text { average slope for each road segment was calculated using zonal } \\
\text { statistics. }\end{array}$ \\
\hline Aspect & $\begin{array}{l}\text { The aspect was calculated in degrees using an input DEM. The aspect is } \\
\text { the direction of the slope. Then the average aspect for each road } \\
\text { segment was calculated using zonal statistics. }\end{array}$ \\
\hline Snow data & $\begin{array}{l}\text { The hillshade was calculated using an input DEM. Hillshade is the } \\
\text { illumination of a surface. Areas with the greatest shadow have a value of } \\
\text { 255 while areas with no shadow are coded as 0. The average hillshade } \\
\text { for each road segment was then calculated using zonal statistics. }\end{array}$ \\
\hline $\begin{array}{l}\text { SnowData contains simulated information on various snow related } \\
\text { factors for a number of years. Since there were no data for 2015 (when } \\
\text { the roads in this study were from) a 5-year average, 2008-2012, was } \\
\text { taken. Zonal statistics were then applied to the 5-year average product. }\end{array}$ \\
\hline $\begin{array}{l}\text { To estimate the human impact on roads, the distance from each road } \\
\text { segment to the nearest urban area was calculated. If the road was } \\
\text { located within the Census defined urban area, the distance was 0. }\end{array}$ \\
\hline Hrban Areas
\end{tabular}




\section{Modeling Pavement Cracks}

The acquired, formatted data were used to elicit a more thorough investigation of infrastructure in Alaska and of the potential impact of permafrost thaw on road cracks, specifically, by answering the following questions:

\section{What landscape features are related to pavement cracks in}

Alaska? (Answers to this question could help to more fundamentally determine the relationships between landscape characteristics and road cracks.)

\section{What is the probability of the road at any given location cracking?}

\subsection{Data down Selection}

Using ArcGIS (as previously discussed) each landscape characteristic was summarized to each road segment. A table containing all of this information was then exported to Microsoft Excel where the data were manually examined and filtered through a Quality Assurance/Quality Control (QA/QC) process, in which any road segments that had missing data were removed so as to not confuse the statistical analysis. The newly cleaned table was then imported into the IBM SPSS Statistics statistical programming software.*

All of the variables were first evaluated for their variance inflation factor (VIF). The VIF is a measure of multi-colinearity, which indicates that two or more variables are highly correlated. If there is multi-colinearity then one variable may be over-predicting. An example of colinearity in this model were snow days and snow free days since both variables measure a similar characteristic. In fact, snow free days $=365-$ snow days. Table 5 summarizes the VIF. Before proceeding to the regression, variables with VIFs greater than 10 were removed to reduce multi-colinearity. Removing the VIFs was important to do before starting a regression analysis so that variables did not over-influence the model results. Note that the VIF was only able to assess variables that were of a continuous data type. Land cover data were excluded from the VIF because it was discreet-being broken into a dozen land cover types.

* International Business Machines (IBM). 
Table 5. Coefficients and VIFs for factors.

\begin{tabular}{|c|c|c|c|c|c|c|c|}
\hline \multicolumn{8}{|c|}{ Coefficients a } \\
\hline & \multicolumn{2}{|c|}{$\begin{array}{l}\text { Unstandardized } \\
\text { Coefficients }\end{array}$} & \multirow{2}{*}{$\begin{array}{c}\begin{array}{c}\text { Standardized } \\
\text { Coefficients }\end{array} \\
\text { Beta }\end{array}$} & \multirow[b]{2}{*}{$\mathrm{T}$} & \multirow[b]{2}{*}{ Sig. } & \multicolumn{2}{|c|}{ Collinearity Statistics } \\
\hline & B & Std. Error & & & & Tolerance & VIF \\
\hline (Constant) & 0.246 & 0.648 & & 0.38 & 0.704 & & \\
\hline air_temp & -0.033 & 0.004 & -0.109 & -8.951 & 0 & 0.333 & 3.002 \\
\hline last_s_d & 0.012 & 0.003 & 0.246 & 3.513 & 0 & 0.01 & 99.607 \\
\hline Rain_on_ & -0.015 & 0.004 & -0.038 & -3.507 & 0 & 0.411 & 2.434 \\
\hline S_1_doy & 0.002 & 0.001 & 0.045 & 2.484 & 0.013 & 0.15 & 6.676 \\
\hline S_days & 0.002 & 0.002 & 0.096 & 1.465 & 0.143 & 0.011 & 88.004 \\
\hline S_free_d & -0.015 & 0.003 & -0.303 & -4.244 & 0 & 0.01 & 103.416 \\
\hline s_up_doy & -0.005 & 0.001 & -0.12 & -3.793 & 0 & 0.049 & 20.238 \\
\hline t_s_days & -0.004 & 0.001 & -0.167 & -2.717 & 0.007 & 0.013 & 76.255 \\
\hline Thermok & $-1.71 \mathrm{E}-06$ & 0 & -0.087 & -8.242 & 0 & 0.447 & 2.236 \\
\hline AK_Wetl & 3.84E-06 & 0 & 0.043 & 5.407 & 0 & 0.794 & 1.259 \\
\hline ALBEDO & -0.003 & 0 & -0.075 & -6.97 & 0 & 0.428 & 2.339 \\
\hline PermProb & 4.01E-05 & 0 & 0.002 & 0.257 & 0.797 & 0.982 & 1.018 \\
\hline HILLSHADE & 0.002 & 0.001 & 0.026 & 2.941 & 0.003 & 0.633 & 1.58 \\
\hline SLOPE_D & 0.007 & 0.003 & 0.023 & 2.76 & 0.006 & 0.688 & 1.453 \\
\hline ASPECT_ & 0 & 0 & -0.02 & -2.667 & 0.008 & 0.852 & 1.174 \\
\hline Urban & $-5.91 \mathrm{E}-07$ & 0 & -0.125 & -9.891 & 0 & 0.308 & 3.247 \\
\hline FireAre & 4.95E-06 & 0 & 0.127 & 12.351 & 0 & 0.47 & 2.129 \\
\hline
\end{tabular}

\subsection{Logistic regression modeling}

A logistic regression was conducted to determine the probability of roads cracking, where probability of a binary outcome is determined based on various predictor values. The dependent variable was a coded binary-if a road was cracked (1) or not cracked (o). Roads were determined to be cracked if more than $2 \%$ of the segments length was cracked (for more information see Section 3.3, p 18). This is then tested against a set of independent variables that were downselected from a larger list using VIF (see Section 4.1, p. 22). The list of variables used in the logistic regression were:

- Air Temperature (Air_Temp)

- Rain on snow (Rain_on_)

- Date of the first day of snow (s_1_dos)

- Distance to thermokarst features (Thermok)

- Distance to wetlands (AK_Wetl)

- Distance to fire (FireAre)

- Soil albedo (ALBEDO) 
- Probability of the presence of permafrost (PermProb)

- Hillshade (HILLSHADE)

- Slope (SLOPE_D)

- Aspect (ASPECT_)

- Distance to urban areas (Urban)

- Land cover.

A Binomial Logistic Regression was run using IBM SPSS Statistics software (IBM 2017a). Of the variables used, only one was a categorical variable (Land Cover Type) that required a special classification. The Land Cover data were broken into eight categories. In the "Define Categorical Variables" option within SPSS, "Indicator" was selected as the change contrast (IBM 2017a). The default probability threshold was accepted, so if the likelihood of a crack forming is $>$ 0.5 , it is assumed to be cracked; if it is $<0.5$, it is assumed to be not cracked.

Table 6. Results of logistic regression.

\begin{tabular}{|c|c|c|c|c|c|}
\hline & B & S.E. & Wald & Sig. & $\operatorname{Exp}(B)$ \\
\hline air_temp & -0.263 & 0.016 & 262.151 & 0 & 0.769 \\
\hline Rain_on_ & -0.138 & 0.02 & 48.233 & 0 & 0.871 \\
\hline s_1_dos & 0.002 & 0.002 & 0.584 & 0.445 & 1.002 \\
\hline Thermok & 0 & 0 & 170.722 & 0 & 1 \\
\hline AK_Wetl & 0 & 0 & 26.306 & 0 & 1 \\
\hline FireAre & 0 & 0 & 267.569 & 0 & 1 \\
\hline ALBEDO & -0.026 & 0.002 & 138.21 & 0 & 0.975 \\
\hline PermProb & 0.002 & 0.001 & 5.819 & 0.016 & 1.002 \\
\hline HILLSHADE & 0.014 & 0.004 & 9.952 & 0.002 & 1.014 \\
\hline SLOPE_D & 0.035 & 0.014 & 6.496 & 0.011 & 1.036 \\
\hline ASPECT_ & -0.001 & 0 & 9.13 & 0.003 & 0.999 \\
\hline Urban & 0 & 0 & 254.893 & 0 & 1 \\
\hline NLCD_Group* & & & 46.005 & 0 & \\
\hline NLCD_Group (1) & 0.715 & 0.802 & 0.795 & 0.373 & 2.045 \\
\hline NLCD_Group (2) & 0.193 & 0.155 & 1.546 & 0.214 & 1.213 \\
\hline NLCD_Group (3) & 0.002 & 0.081 & 0.001 & 0.98 & 1.002 \\
\hline NLCD_Group (4) & 0.148 & 0.088 & 2.806 & 0.094 & 1.159 \\
\hline NLCD_Group (5) & 0.546 & 0.545 & 1.004 & 0.316 & 1.726 \\
\hline NLCD_Group (6) & -0.842 & 0.315 & 7.146 & 0.008 & 0.431 \\
\hline NLCD_Group (7) & -0.312 & 0.105 & 8.892 & 0.003 & 0.732 \\
\hline NLCD_Group (8) & 0.253 & 0.284 & 0.791 & 0.374 & 1.288 \\
\hline Constant (a) & -1.835 & 0.805 & 5.194 & 0.023 & 0.16 \\
\hline
\end{tabular}




\subsection{Map production}

The results of the logistic regression were then applied back onto the input variable data. For variables in the final model that were calculated using the near tool (thermokarst, wetlands, fire, and urban area), a surface raster was first generated to calculate the distance from each feature to every cell on the map as a means of creating an equivalent dataset. Figure 9 shows the newly created distance raster for urban areas. Areas that are darker are closer to/within an urban area while white areas are farther away.

The next step was to multiply each raster by the constant value (B) produced in IBM SPSS Statistics. As the analysis was conducted, however, it was found that there were issues with extents, cell size, and projection of the data. These issues resulted in analysis outputs that had no associated error message, but were clearly displaying incorrect results.

Figure 9. New raster created by calculating the distance from urban areas.

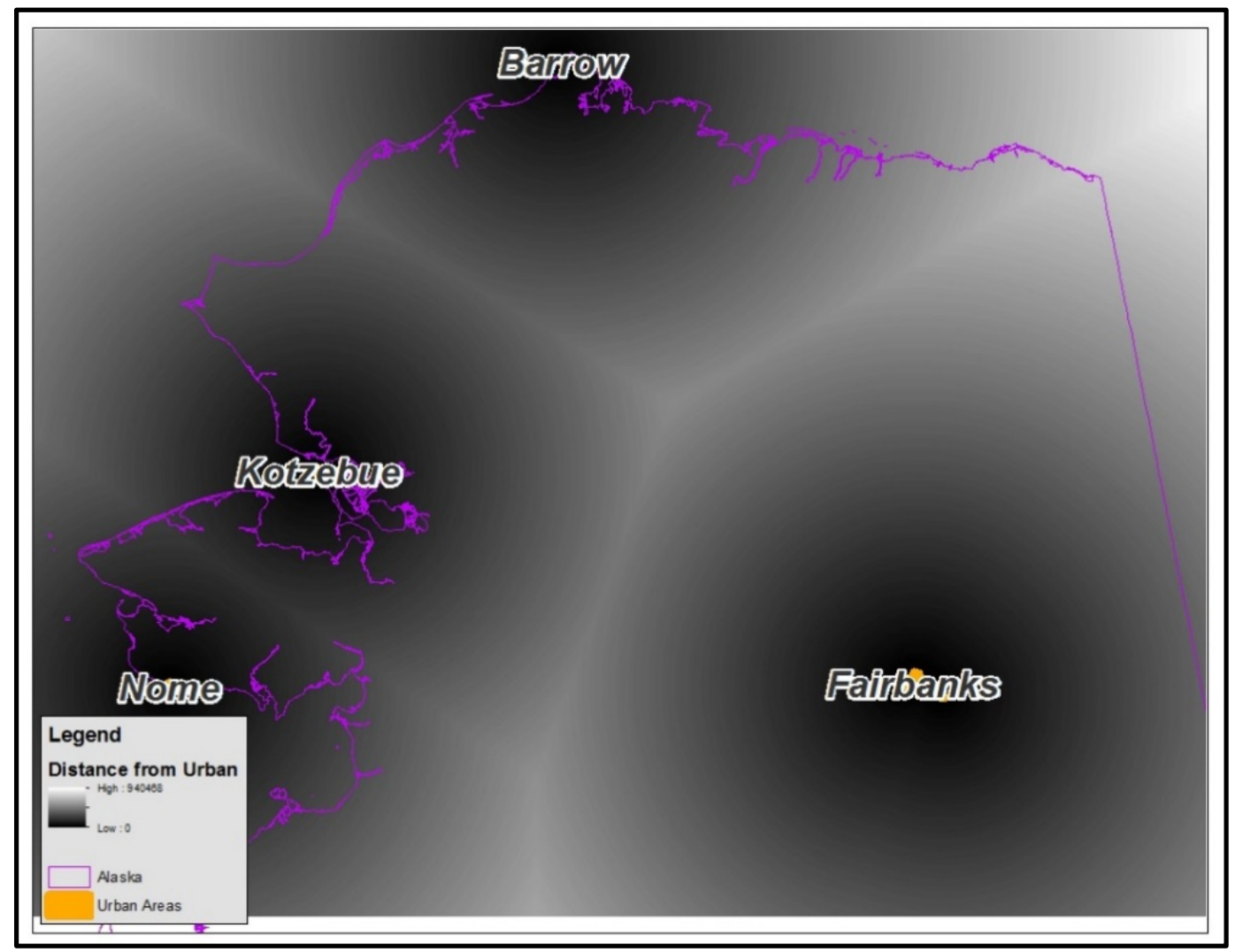


After much trial and error within the data, a script was finally developed using ArcGIS Model Builder that would process the data appropriately (Figure 10). A "master raster" that had the projection, appropriate cell size, and extent for the analysis was developed. This raster (Masked_Area) was then used as a template for the rest of the rasters. Each value raster was first projected to be in "NAD_1927_Albers,"” a projected coordinate system measured in feet, in which the projection and the extent were set to the template raster. In other words, that the output raster would have the NAD_1927_Albers projection and its extent would match the template. The data were then resampled to a new cell size of $2000 \mathrm{x} 2000 \mathrm{ft}$. This size was selected because of computational issues that required data to be processed at a smaller cell size. Finally, a python script was used to identify the correct constant (B) value for the raster, and then each raster cell was multiplied by that value.

Figure 10. Screen shot of the final data processing tool developed using ArcGIS pro. This tool enabled the rapid processing of input variable data.

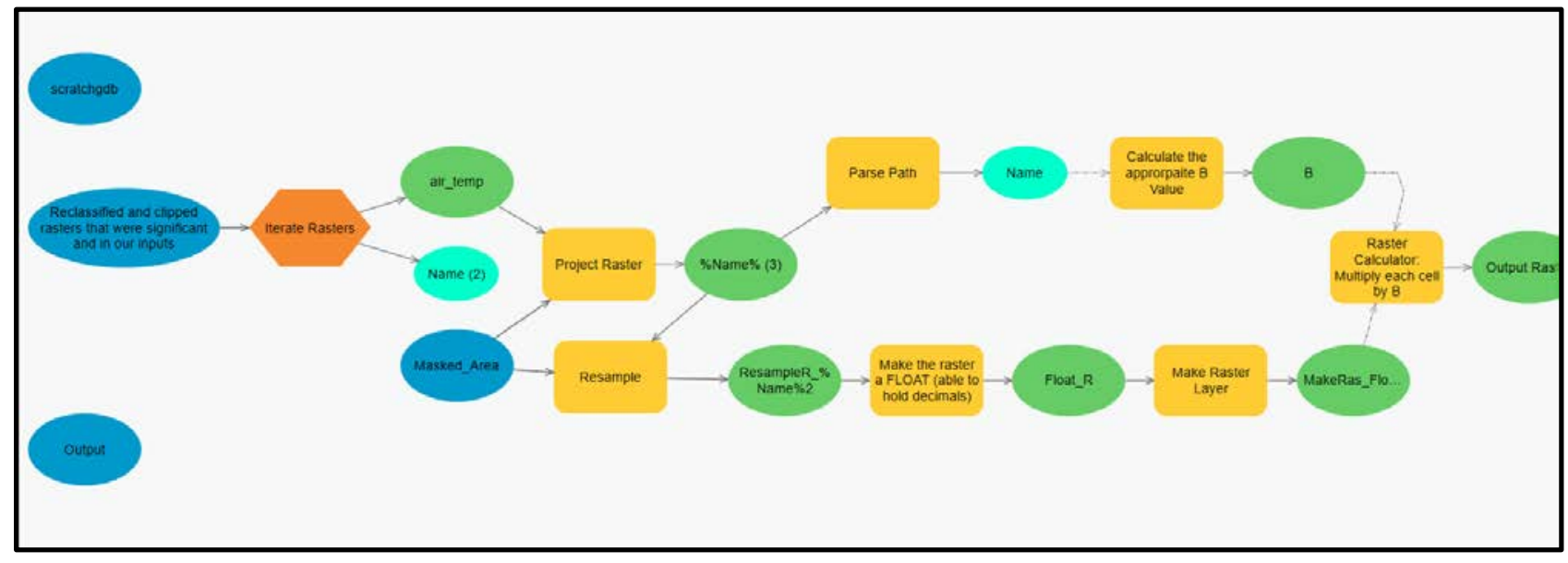

The result was a series of raster files such as the one shown in Figure 11, which demonstrates the output generated when the input raster (slope) was multiplied by the constant value from the logistic regression (-0.0380221114420544) to produce an output raster with values ranging from -1.6 - o. This stands in contrast to the input slope dataset, which had values ranging from $\mathrm{O}-45$.

* Note: NAD = “North American Datum“ 
Figure 11. Illustration of the output of multiplying slope by the variable coefficient from the statistical analysis.

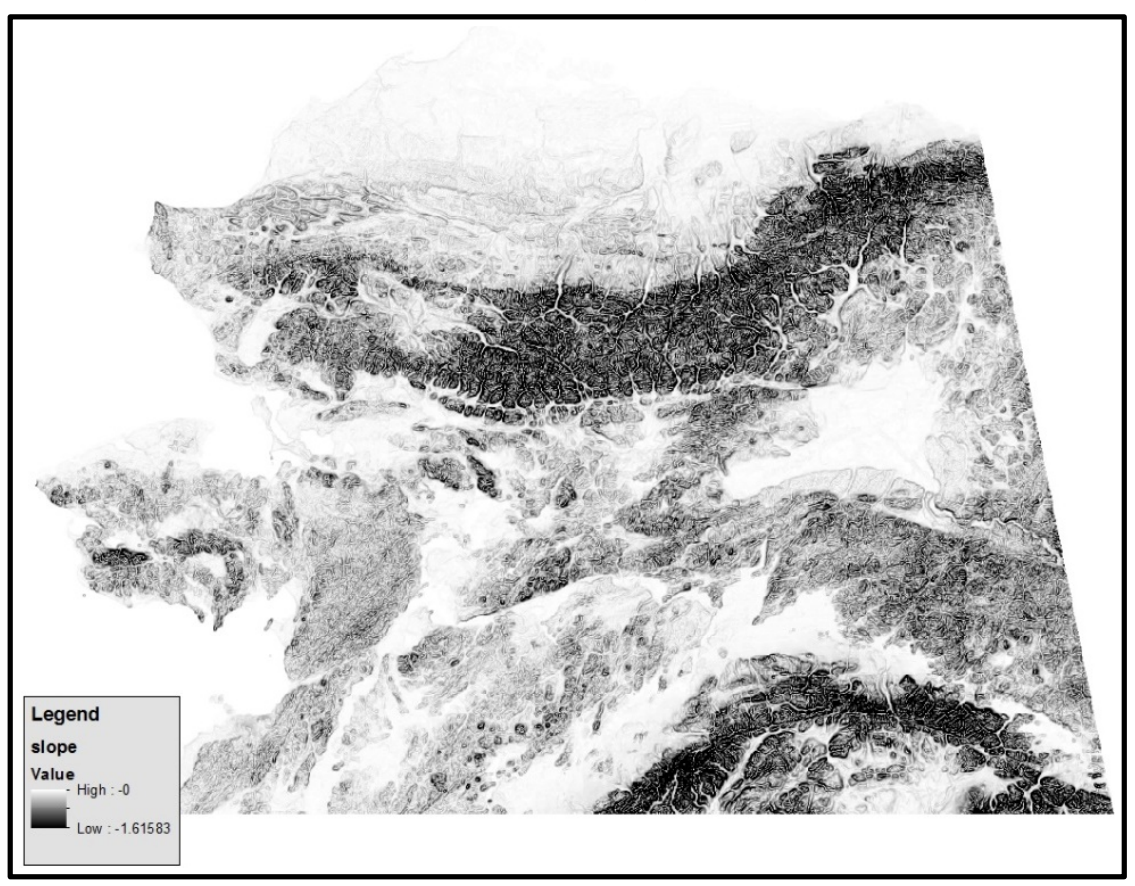

The probability of roads cracking using the logistic regression formula was calculated using the raster calculator function in ArcGIS:

$$
\mathrm{p}=\frac{\mathrm{e}^{a+b_{1} x_{1}+b_{2} x_{2}+\ldots}}{1+e^{a+b_{1} x_{1}+b_{2} x_{2}+\ldots}}
$$

where:

$\mathrm{P}=$ Probability of " 1 " (roads cracking)

$\mathrm{A}=$ constant (from "B" column of "Variables in the Equation" table); bi = coefficients (from " $\mathrm{B}$ " column of "Variables in the Equation" table)

$\mathrm{Xi}=$ variable values. 


\section{Results}

\subsection{Limitations}

1. Cell size: The probability map produced through this analysis was done using generalized cell sizes of $2000 \mathrm{x} 2000 \mathrm{ft}$. In other words, data were taken from its original resolution (generally between $30-90 \mathrm{~m}$ ) and aggregated so that each cell was $2000 \mathrm{x} 2000 \mathrm{ft}$. The resampling process was used to gain computational processing speed, which was required because of limitations on the computer being used. The trade-off, however, was that nuances in the landscape and data were lost.

\section{Lack of key variables:}

a. One of the key missing factors from this analysis were any soil related characteristics. The initial model setup did include data from Soil Survey Geographic (SSURGO) database from the National Cooperative Soil Survey (USDA 2017). Unfortunately, the breadth of values presented in that dataset resulted in a truncated data output and the SSURGO data had to be removed. Soil moisture was excluded from the analysis because it was not possible to obtain a dataset at a fine enough resolution. Since the conclusion of the analysis, an improved dataset has been acquired.

b. Also missing from this analysis were vegetation data via leaf-area index, tree-line, or normalized difference vegetation index (NDVI). The NDVI is available from the USGS and is cumbersome to download and process. The data are provided as individual tiles that are individually downloaded, and then need to be combined. Given time constraints of this research, the NDVI had to be excluded.

3. Exclusions: One way to produce a more explanatory graphic and analysis is to exclude areas that are known to be unsuitable for development from the final mapping portion. The analysis presumes that all land in Alaska is suitable for road construction and does not exclude areas that are known to be non-conducive to road construction-such as areas having a high slope or bodies of water.

\subsection{Results discussion}

The logistic regression model developed provides an initial estimate of locations in Northern Alaska where roads may crack. The data in Table 7 summarize the model output. The logistic regression model correctly predicted the presence of cracks $63.7 \%$ of the time. The model results are 
skewed, in that they only correcting predict the lack of a crack $31.6 \%$ of the time while they correctly predict cracks $86.5 \%$ of the time. While a higher fit is desirable, a correct classification of over $50 \%$ demonstrates a strong model. For this analysis, the cut percentage was 50\%. In other words, if it had a value of $50 \%$ or greater, it was coded as cracked; if it had a value under 50\%, it was coded as not cracked.

Table 7. Classification resulting from the logistic regression.

\begin{tabular}{|l|c|c|c|c|}
\hline \multirow{2}{*}{\multicolumn{2}{|c|}{ Observed }} & \multicolumn{3}{|c|}{ Predicted } \\
\cline { 3 - 4 } & & \multicolumn{2}{|c|}{ Crack_Presence } & \multirow{2}{*}{ Percentage Correct } \\
\cline { 3 - 5 } & No (0) & Yes (1) & 31.6 \\
\hline Crack_Presence & No (0) & 1793 & 3875 & 86.5 \\
\cline { 3 - 5 } & Yes (1) & 1067 & 6866 & 63.7 \\
\hline Overall Percentage & & & \\
\hline
\end{tabular}

The mapped results shown in Figure 12 show that many areas in Alaska have a low probability of roads cracking while a few concentrated areas demonstrate a high probability.

- Lower probability of roads cracking in northern Alaska. This is likely due to several factors: the sparse population (high distance from an urban area), presence of continuous permafrost, and minimal precipitation. In the original data from the Alaskan department of transportation, there were fewer large road cracks in the north compared to the south.

- Air Temperature. In the model, air temperature, which was estimated from SNOWDATA, had a tremendous impact on the final results. The map shown in Figure 13 shows areas with higher temperatures in darker blue. The purple boxes on the map, which indicate areas with a higher probability of cracking, also all had higher temperatures, indicating a link between temperature and probability of road cracking.

- Minimal effect urban areas. One expected result from this research was that there would be more road cracking around urban areas. This was tied to the likely assumption that many of the road cracks were a result of driving and road wear that come from heavy use. However, urban areas in Alaska are not very large. U.S. Census figures show that Fairbanks has a population of about 64,000 , and the Nome area has a population of about 3,300. A way to improve the counting of road use from human use would be to use population estimates. 
Figure 12. Mapped results of the probability of roads cracking in Alaska.

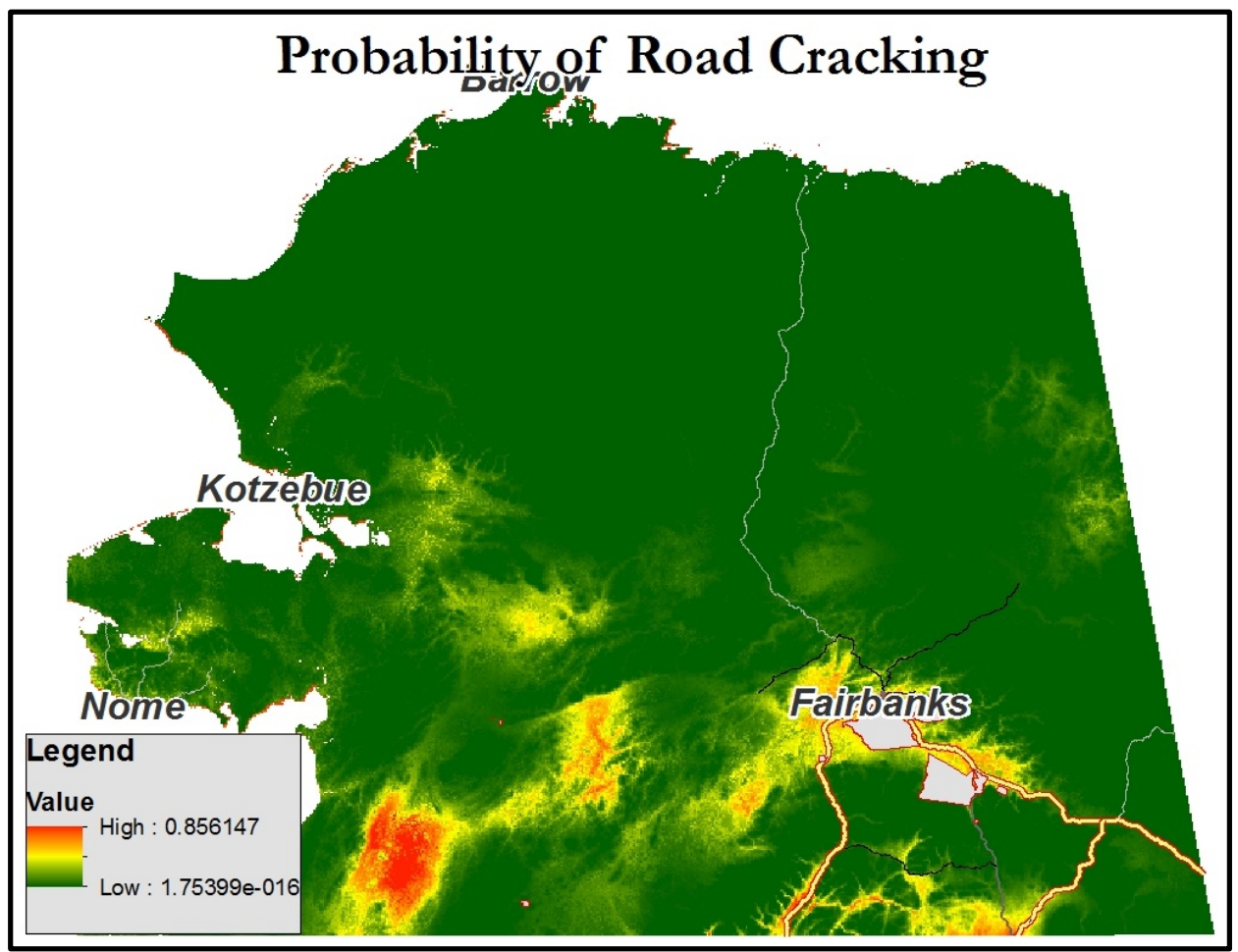

Figure 13. Map illustrating air temperature data from SnowData mapped in relationship to the areas of high probability of cracking (purple boxes).

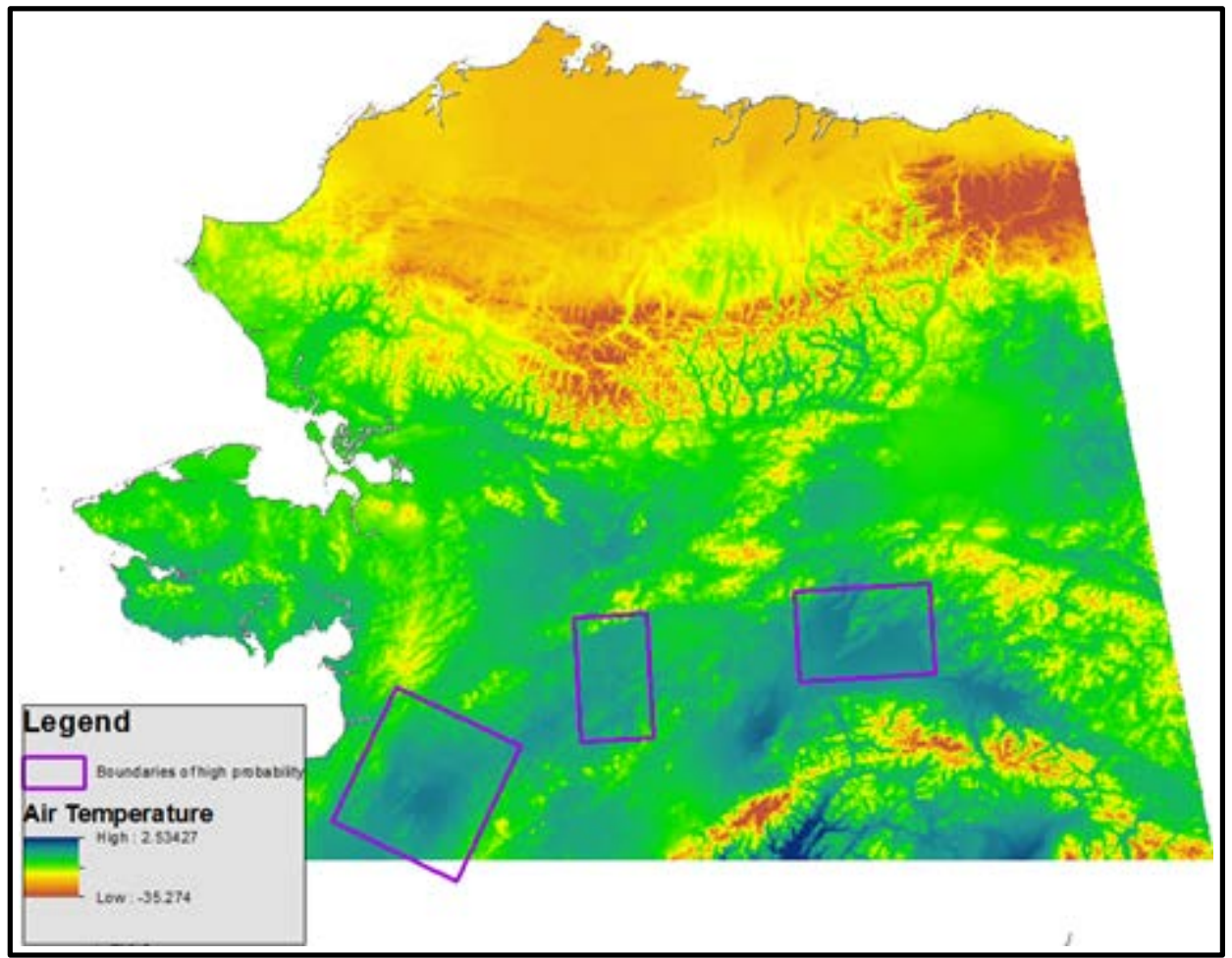




\section{References}

AICC (Alaska Interagency Coordination Center). 1986. "Historical Lightning." Website. Fort Wainwright, AK: AICC, https://fire.ak.blm.gov/predsvcs/maps.php

2016b. AICC ArcMIS mapping products: Fire perimeter shape file download, Predictive Services - Maps/Imagery/Geospatial, https://fire.ak.blm.gov/predsvcs/maps.php

AKDOT (Alaska Department of Transportation). 2016. Overall pavement data for 2014 and 2015. 2014 \& 2105 Pavement Data. Website, http://www.arcgis.com/home/item.html?id=7e98d93f8f3b4e24aac4491afd9dae18

Arp, C. D., B. M. Jones, M. Whitman, A. Larsen, and F. E. Urban. 2010. Lake temperature and ice cover regimes in the Alaskan subarctic and arctic: Integrated monitoring, remote sensing, and modeling. JAWRA Journal of the American Water Resources Association 46 (4):777-91, https://doi.org/10.1111/j.1752$\underline{1688.2010 .00451 . x}$

Brown, J, O. J. Ferrians, J. A. Heginbottom, and E. S. Melnikov. 2001. "Circum-Arctic map of permafrost and ground ice conditions." Boulder, CO: National Snow and Ice Data Center (NSIDC).

Cote, Michelle M. 2002. The Influence of Elevation and Aspect on Permafrost Distribution in Central Yukon Territory. Master's Thesis. Carleton University Research Virtual Environment. Ottawa, Canada: Carleton University, https://curve.carleton.ca/1c1c6722-2de3-4aa9-9b11-acc93cdcc026

Dublin, Robin, Jonne Slemons, Karen L. Lew, and Conrad J. Field. 2001. Alaska's Tundra \& Wildlife.” Juneau, AK: Alaska Department of Fish and Game.

Esri. 2014. ArcGIS Help 10.2, 2014: Zonal statistics (spatial analyst). ArcGIS Resources. Web site. Redlands, CA: Esri, http://resources.arcgis.com/EN/HELP/MAIN/10.2/index.html\#//009z000000w7000000

2017. ArcMap: Near. ArcGIS for Desktop. Web site. Redlands, CA: Esri, http://desktop.arcgis.com/en/arcmap/10.3/tools/coverage-toolbox/near.htm

Farouki, Omar T. 1981. Thermal Properties of Soils. CRREL Monograph 81-1. Hanover, $\mathrm{NH}$ : Cold Regions Research and Engineering Laboratory (CRREL), http://www.dtic.mil/dtic/tr/fulltext/u2/a111734.pdf

Fischer, Howard. 2014. Environmental groups drop suit over Fort Huachuca's effect on San Pedro River. East Valley Tribune, 16 May 2014, http://www.eastvalleytribune.com/arizona/politics/article_f025b14a-dd49-11e3-b24c001a4bcf887a.html

Fryer, Janet. 2014. Picea mariana. Fire Effects Information System (FEIS). U.S. Department of Agriculture, Forest Service, Rocky Mountain Research Station, Fire Sciences Laboratory, http://www.fs.fed.us/database/feis/plants/tree/picmar/all.html 
Groose, Guido. 2015. Intro to Remote Sensing of Permafrost Landscapes and Dynamics. Potsdam, Germany: University of Potsdam, Alfred Wegener Institute, Periglacial Research Unit, https://epic.awi.de/41741/1/Grosse_Intro_Remote_Sensing_Permafrost_Homer.pdf

Guo, Jinting, Yuanman Hu, Zaiping Xiong, Xiaolu Yan, Chunlin Li, and Rencang Bu. 2017. Variations in growing-season NDVI and its response to permafrost degradation in Northeast China. Sustainability 9(4):551, https://doi.org/10.3390/su9040551

Hall, Dorothy K., and George A. Riggs. 2007. Accuracy assessment of the MODIS snow products. Hydrological Processes 21(12):1534-47, https://doi.org/10.1002/hyp.6715

Hugelius, G., C. Tarnocai, G. Broll, J. G. Canadell, P. Kuhry, and D. K. Swanson. 2013. The northern circumpolar soil carbon database: Spatially distributed datasets of soil coverage and soil carbon storage in the Northern Permafrost Regions. Earth System Science Data 5(1):3-13, https://doi.org/10.5194/essd-5-3-2013

IBM (International Business Machines Corp). 2017a. Logistic regression. IBM Knowledge Center. Website. Armonk, NY: IBM, https://www.ibm.com/support/knowledgecenter/en/SSLVMB_22.0.0/com.ibm.spss.statistics. help/spss/regression/idh_Ireg.htm

2017b. Logistic regression define categorical variables. IBM Knowledge Center. Armonk, NY: IBM, https://www.ibm.com/support/knowledgecenter/en/SSLVMB_22.0.0/com.ibm.spss.statistics. help/spss/regression/idh_Ireg_cat.htm\#idh_Ireg_cat

Jones, Benjamin M., Guido Grosse, Kenneth M. Hinkel, Christopher D. Arp, Shane Walker, Richard A. Beck, and John P. Galloway. 2012. Assessment of pingo distribution and morphometry using an IfSAR Derived Digital Surface Model, Western Arctic Coastal Plain, Northern Alaska. Geomorphology 138(1):1-14, http://www.sciencedirect.com/science/article/pii/S0169555X11004053

Jorgenson, M. Torre. Joanna E. Roth, Michael D. Smith, Sharon Schlentner, Will Lentz, Erik R. Pullman, and Charles H. Racine. 2001. An Ecological Land Survey for Fort Greely, Alaska. Hanover, NH: CRREL, Inc., http://www.dtic.mil/dtic/tr/fulltext/u2/a391120.pdf

Kanevskiy, M., Y. Shur, M. T. Jorgenson, C. -L. Ping, G. J. Michaelson, D. Fortier, E. Stephani, M. Dillon, and V. Tumskoy. 2013. Ground ice in the upper permafrost of the Beaufort Sea coast of Alaska. Cold Regions Science and Technology 85(January 2013):56-70, https://doi.org/10.1016/i.coldregions.2012.08.002

Kelley, Alexia M., Howard E. Epstein, and Donald A. Walker. 2004. Role of vegetation and climate in permafrost active layer depth in arctic tundra of Northern Alaska and Canada. Journal of Glaciology and Geocryology 26(S1):269-274, http://www.geobotany.org/library/pubs/KelleyAM2004_igc_26_269.pdf 
Kokelj, S. V., J. Tunnicliffe, D. Lacelle, T. C. Lantz, K. S. Chin, and R. Fraser. 2015. Increased Precipitation Drives Mega Slump Development and Destabilization of Ice-Rich Permafrost Terrain, Northwestern Canada. Global and Planetary Change 129(June):56-68, https://doi.org/10.1016/i.gloplacha.2015.02.008

Larsen, P., S. Goldsmith, O, Smith, M. Wilson, K. Strzepek, P. Chinowsky, and B. Saylor. 2008. Estimating future costs for Alaska public infrastructure at risk from climate change. Global Environmental Change 18(3):442-57, https://doi.org/10.1016/j.gloenvcha.2008.03.005

Lawrence, D. M., C. D. Koven, S. C. Swenson, W. J. Riley, and A. G. Slater. 2015. Permafrost thaw and resulting soil moisture changes regulate projected highlatitude $\mathrm{CO}_{2}$ and $\mathrm{CH}_{4}$ emissions. Environmental Research Letters 10(9):094011, https://doi.org/10.1088/1748-9326/10/9/094011

LCC (Arctic Landscape Conservation Cooperative). 2017. SnowDATA annual summaries. Arctic Landscape Conservation Cooperative: Advancing Science, Understanding Change. Fairbanks, AK: U.S. Fish and Wildlife Service (USFWS), http://arcticlcc.org/products/spatial-data/show/snowdata-annual-summaries

Liljedahl, Anna K., Julia Boike, Ronald P. Daanen, Alexander N. Fedorov, Gerald V. Frost, Guido Grosse, Larry D. Hinzman, Yoshihiro Iijma, Janet C. Jorgenson, Nadya Matveyeva, Marius Necsoiu, Martha K. Raynolds, Vladimir E. Romanovsky, Jörg Schulla, Ken D. Tape, Donald A. Walker, Cathy J. Wilson, Hironori Yabuki, and Donatella Zona. 2016. Pan-Arctic ice-wedge degradation in warming permafrost and its influence on tundra hydrology." Nature Geoscience 9(4): 312-18, https://doi.org/10.1038/ngeo2674

Liston, Glen E., and Christopher A. Hiemstra. 2008. A simple data assimilation system for complex snow distributions (SnowAssim). Journal of Hydrometeorology 9(5): 989-1004, https://doi.org/10.1175/2008JHM871.1

Liston, G. E., and C. A. Hiemstra. 2011. The changing cryosphere: Pan-Arctic snow trends (1979-2009). Journal of Climate 24(21):5691-5712.

Miller, James A., and R. L. Whitehead. 1999. Ground Water Atlas of the United States Alaska, Hawaii, Puerto Rico and the U.S. Virgin Islands.” HA 730-N. Reston, VA: U.S. Geological Survey (USGS), https://pubs.usgs.gov/ha/ha730/ch_n/NAKtext1.html

Mishra, U., and W. J. Riley. 2012. Alaskan soil carbon stocks: Spatial variability and dependence on environmental factors. Biogeosciences 9(9):3637-45, https://doi.org/10.5194/bg-9-3637-2012

MRLC (Multi-Resolution Land Characteristics Consortium). 2014. Product data downloads. National Land Cover Database 2011 (NLCD2011). Website. Washington, DC: U.S. Department of the Interior (USDOI), USGS, https://www.mrlc.gov/nlcd11_data.php 
Muskett, Reginald R., and Vladimir E. Romanovsky. 2009. Groundwater storage changes in Arctic permafrost watersheds from GRACE and in situ measurements. Environmental Research Letters 4(4), https://doi.org/10.1088/1748$\underline{9326 / 4 / 4 / 045009}$

Myneni, Ranga B. 2013. Climate and Vegetation Research Group. Web page. Boston, MA: Boston University, Department of Earth and Environment, http://cliveg.bu.edu/modismisr/lai3g-fpar3g.html

NASA (National Aeronautics and Space Administration). 2017. GPM data downloads. Precipitation Measurement Missions. Greenbelt, MD: Goddard Space Center, https://pmm.nasa.gov/data-access/downloads/gpm

NCADAC (Federal National Climate Assessment and Development Advisory Committee). 2014. Climate Change Impacts in the United States: U.S. National Climate Assessment. Washington, DC: 2014 National Climate Assessment. U.S. Global Change Research Program, https://nca2014.globalchange.gov

NGA (National Geospatial-Intelligence Agency). 2012. Digital terrain elevation data. NGA Products and Services. Website. Springfield, VA: NGA, https://www.nga.mil/ProductsServices/TopographicalTerrestrial/Pages/DigitalTerrainElevationD ata.aspx

NRC (National Research Council). 2015. Opportunities to Use Remote Sensing in Understanding Permafrost and Related Ecological Characteristics: Report of a Workshop. Washington, DC: The National Academies Press, https://doi.org/10.17226/18711

NRCS (Natural Resources Conservation Service). 2017. "USA Soils Albedo.” Washington, DC: U.S. Department of Agriculture (USDA), NRCS, Esri, http://www.arcgis.com/home/item.html?id=e89fdc8e8b13417daa5ad232312f58cf

NSIDC (National Snow and Ice Data Center). 2017. SMAP data, NASA Distributed Active Archive Center (DAAC) at NSIDC. Boulder, CO: University of Colorado, NSIDC, http://nsidc.org/data/smap/smap-data.html

Nossov, Dana R., M. Torre Jorgenson, Knut Kielland, and Mikhail Z. Kanevskiy. 2013. Edaphic and microclimatic controls over permafrost response to fire in interior Alaska. Environmental Research Letters 8(3):035013, https://doi.org/10.1088/1748-9326/8/3/035013

Olefeldt, D., S. Goswami, G. Grosse, D.J. Hayes, G. Hugelius, P. Kuhry, B. Sannel, E.A.G. Schuur, and M.R. Turetsky. 2016. Arctic Circumpolar Distribution and Soil Carbon of Thermokarst Landscapes, 2015. Oak Ridge, TN: ORNL DAAC, https://doi.org/10.3334/ORNLDAAC/1332

Oht, M. 2003. Impact of meteorological factors on active layer development in central Spitsbergen. Proceedings 8th International Permafrost Conference, Zürich, Switzerland, 2:845-850, http://www.arlis.org/docs/vol1/ICOP/55700698/Pdf/Chapter_148.pdf 
Olefeldt, D., S. Goswami, G. Grosse, D. J. Hayes, G. Hugelius, P. Kuhry, B. Sannel, E. A. G. Schuur, and M. R. Turetsky. 2016. Arctic Circumpolar Distribution and Soil Carbon of Thermokarst Landscapes, 2015. Oak Ridge, TN: Oak Ridge National Laboratory (ORNL), Distributed Active Archive Center (DAAC), https://doi.org/10.3334/ORNLDAAC/1332

Osterkamp, T. E. 2005. The recent warming of permafrost in Alaska. Global and Planetary Change 49(3-4):187-202, https://doi.org/10.1016/i.gloplacha.2005.09.001

Park, Hotaek, Alexander N. Fedorov, Mikhail N. Zheleznyak, Pavel Y. Konstantinov, and John E. Walsh. 2015. Effect of snow cover on pan-arctic permafrost thermal regimes. Climate Dynamics 44(9-10):2873-95, https://doi.org/10.1007/s00382$\underline{014-2356-5}$

Pastick, Neal J., M. Torre Jorgenson, Bruce K. Wylie, Burke J. Minsley, Lei Ji, Michelle A. Walvoord, Bruce D. Smith, Jared D. Abraham, and Joshua R. Rose. 2013. Extending airborne electromagnetic surveys for regional active layer and permafrost mapping with remote sensing and ancillary data, Yukon Flats Ecoregion, Central Alaska: remote sensing and mapping of permafrost and active-layer thickness. Permafrost and Periglacial Processes 24(3):184-99, https://doi.org/10.1002/ppp.1775

Pastick, Neal J., M. Torre Jorgenson, Bruce K. Wylie, Shawn J. Nield, Kristofer D. Johnson, and Andrew O. Finley. 2015. Probabilistic Estimates of the Distribution of Near-Surface Permafrost in Alaska. Washington, DC: USGS, https://doi.org/10.5066/F7C53HX6

Péwé, Troy L. 2018. Permafrost. Encyclopædia Britannica. Website. Chicago, IL: Encyclopædia Britannica, https://www.britannica.com/science/permafrost

Romanovsky, V. E., S. S. Marchenko, R. Daanen, D. O. Sergeev, and D. A. Walker. 2008. Soil climate and frost heave along the permafrost/ecological North American arctic transect. Proceedings of the Ninth International Conference on Permafrost 2:1519-1524. Fairbanks, AK: Institute of Northern Engineering, https://www.researchgate.net/profile/Ronald_Daanen/publication/233764550_Soil_climate and_frost_heave_along_the_PermafrostEcological_North_American_Arctic_Transect/links/0dee c52fa827d14947000000.pdf

Romps, D. M., J. T. Seeley, D. Vollaro, and J. Molinari. 2014. Projected increase in lightning strikes in the United States due to global warming. Science 346(6211):851-54, https://doi.org/10.1126/science.1259100

Safford, L. O., and John C Bjorkbom. 1975. Betulaceae - Birch Family. Silvics of Forest Trees of the United States Agriculture Handbook No. 271. Washington, DC: U.S. Department of Agriculture, U.S. Forest Service. Timber Management Research.

Simard, M., N. Pinto, J. B. Fisher, and A. Baccini. 2011. Mapping Forest Canopy Height Globally with Spaceborne LIDAR. Journal of Geophysical Research 116:Go4021, doi:10.1029/2011JGoo1708

Szukalski, B.W. 2014. USA karst (features). ArcGIS. Washington, DC: USDA, NRCS, Esri, http://www.arcgis.com/home/item.html?id=bbd7f9b9595b4a8d80bd5f3aca90ec26 
U.S. Census Bureau. 2016. Cartographic boundary shapefiles - Urban areas. Geography. Washington, DC: U.S. Census Bureau, https://www.census.gov/geo/mapsdata/data/cbf/cbf_ua.html

USDA (U.S. Department of Agriculture). 2017. Description of SSURGO Database | NRCS Soils. Web site. Washington, DC: USDA, Natural Resources Conservation Service (NRCS), https://www.nrcs.usda.gov/wps/portal/nrcs/detail/soils/survey/?cid=nrcs142p2_053627

USFWS (U.S. Fish and Wildlife Service). 2016. Wetlands mapper. U.S. Fish and Wildlife Service National Wetlands Inventory. Washington, DC: USFWS, https://www.fws.gov/wetlands/Data/Mapper.html

Veraverbeke, Sander, Brendan M. Rogers, Mike L. Goulden, Randi R. Jandt, Charles E. Miller, Elizabeth B. Wiggins, and James T. Randerson. 2017. Lightning as a major driver of recent large fire years in North American boreal forests. Nature Climate Change 7(7):529-34, https://doi.org/10.1038/nclimate3329

Viereck, L. A., K. Van Cleve, and C. T. Dyrness. 1986. Forest ecosystem distribution in the Taiga environment. Forest Ecosystems in the Alaskan Taiga. New York, NY: Springer, pp 22-43, https://doi.org/10.1007/978-1-4612-4902-3_3

Waldman, Scott. 2017. Lightning-caused fires rise in arctic as the region warms. Scientific American, E \& E News, Weather. Website. 27 June 2017, https://www.scientificamerican.com/article/lightning-caused-fires-rise-in-arctic-as-the-region-warms/

Walvoord, Michelle Ann, and Robert G. Striegl. 2007. Increased groundwater to stream discharge from permafrost thawing in the Yukon River basin: Potential impacts on lateral export of carbon and nitrogen. Geophysical Research Letters 34(12), https://doi.org/10.1029/2007GL030216

Williams, John R. 1970. Ground Water in the Permafrost Regions of Alaska. Geological Survey Professional Paper 696. Washington, DC: U.S. Department of the Interior, Geological Survey, https://pubs.usgs.gov/pp/0696/report.pdf

Wilson, Frederic H., Chad P. Hults, Charles G. Mull, and Susan M. Karl. 2015, Geologic Map of Alaska: U.S. Geological Survey Scientific Investigations Map 3340.

Pamphlet 196. Scale 1:1,584,000, http://dx.doi.org/10.3133/sim3340

Wooster Geologist. 2016. Wooster geologist at Argonne National Laboratory. Wooster Geologists: A World to Explore. Web page. Argonne, IL: Argonne National Laboratory, http://woostergeologists.scotblogs.wooster.edu/2016/07/16/wooster-geologistat-argonne-national-laboratory/

WU (Weather Underground). 2018. Permafrost. Website. San Francisco, CA: The Weather Channel (TWC) Product and Technology LLC, https://www.wunderground.com/climate/permafrost

Zhang, T., and K. Stamnes. 1998. Impact of climatic factors on the active layer and permafrost at Barrow, Alaska. Permafrost and Periglacial Processes 9(3):22946, https://doi.org/10.1002/(SICI)1099-1530(199807/09)9:3<229::AID-PPP286>3.0.C0;2-I 
Zhang, Tingjun. 2005. Influence of the seasonal snow cover on the ground thermal regime: An overview. Reviews of Geophysics 43(4):RG4002, https://doi.org/10.1029/2004RG000157

Zhu, Zhiliang, and McGuire, A. D., eds. 2016. Baseline and Projected Future Carbon Storage and Greenhouse-Gas Fluxes in Ecosystems of Alaska. U.S. Geological Survey Professional Paper 1826. Washington, DC: USGS, http://dx.doi.org/10.3133/pp1826. at http://dx.doi.org/10.3133/pp1826 


\section{Acronyms and Abbreviations}

$\begin{array}{ll}\text { Term } & \text { Definition } \\ \text { AHAP } & \text { AK High Altitude Photography } \\ \text { AKDOT } & \text { Alaska Department of Transportation } \\ \text { AKOATS } & \text { Alaska Online Aquatic Temperature Site } \\ \text { AICC } & \text { Alaska Interagency Coordination Center } \\ \text { ALT } & \text { Active Layer Thickness } \\ \text { BLM } & \text { Bureau of Land Management } \\ \text { CAPS } & \text { Circumpolar Active-Layer Permafrost System } \\ \text { CEMML } & \text { Center for the Environmental Management of Military Lands } \\ \text { CERL } & \text { Construction Engineering Research Laboratory } \\ \text { CONUS } & \text { Continental United States } \\ \text { CRREL } & \text { Cold Regions Research and Engineering Laboratory } \\ \text { DAAC } & \text { Distributed Active Archive Center } \\ \text { DEM } & \text { Digital Elevation Model } \\ \text { DGGS } & \text { Division of Geological \& Geophysical Surveys } \\ \text { DoD } & \text { U.S. Department of Defense } \\ \text { DOT } & \text { Department of Transportation } \\ \text { DTA } & \text { Differential Thermal Analysis } \\ \text { DTED } & \text { Digital Terrain Elevation Data } \\ \text { ERDC } & \text { U.S. Army Engineer Research and Development Center } \\ \text { ERDC-CERL } & \text { Engineer Research and Development Center, Construction Engineering } \\ \text { FEIS } & \text { Research Laboratory } \\ \text { FTP } & \text { Fire Effects Information System } \\ \text { GINA } & \text { File Transfer Protocol } \\ \text { GIPL } & \text { Geographical Information Network of Alaska } \\ \text { GIS } & \text { Geophysical Institute Permafrost Laboratory } \\ \text { GPM } & \text { Geographic Information System } \\ \text { GPP } & \text { Global Precipitation Measurement } \\ \text { GRID } & \text { Gross Primary Productivity } \\ \text { HPMS } & \text { Global Resource Information Database } \\ \text { IBM } & \text { Highway Performance Monitoring System } \\ \text { IfSAR } & \text { International Business Machines (Corp.) } \\ \text { JAWRA } & \text { Interferometric Synthetic Aperture Radar } \\ \text { LAI } & \text { Journal of American Water Resources Association } \\ \text { LCC } & \text { Leaf Area Index } \\ \text { LiDAR } & \text { Lirctic) Landscape Conservation Cooperative } \\ \text { MODIS } & \text { Moderate Resolution Imaging Spectroradiometer } \\ & \end{array}$




$\begin{array}{ll}\text { Term } & \text { Definition } \\ \text { MRLC } & \text { Multi-Resolution Land Characteristics Consortium } \\ \text { NAD } & \text { North American Datum } \\ \text { NASA } & \text { National Aeronautics and Space Administration } \\ \text { NCADAC } & \text { (Federal) National Climate Assessment and Development Advisory } \\ & \text { Committee } \\ \text { NDVI } & \text { Normalized Difference Vegetation Index } \\ \text { NGA } & \text { National Geospatial Intelligence Agency } \\ \text { NLCD } & \text { National Land Cover Datanase } \\ \text { NPP } & \text { Net Primary Productivity } \\ \text { NRC } & \text { National Research Council } \\ \text { NRCS } & \text { Natural Resources Conservation Service } \\ \text { NSIDC } & \text { National Snow and Ice Data Center } \\ \text { NSSI } & \text { North Slope Science Initiative } \\ \text { O\&M } & \text { Operations and Maintenance } \\ \text { PGC } & \text { Polar Geospatial Center } \\ \text { QA/QC } & \text { Quality Assurance/Quality Control } \\ \text { QC } & \text { Quality Control } \\ \text { QPE } & \text { Quantitative Perception Estimates } \\ \text { SAR } & \text { Synthetic Aperture Radar } \\ \text { SMAP } & \text { Soil Moisture Active/Passive } \\ \text { SNAP } & \text { Scenarios Network for Alaska + Arctic Planning } \\ \text { SSURGO } & \text { Soil Survey Geographic } \\ \text { SWOT } & \text { Surface Water Ocean Topography } \\ \text { TR } & \text { Technical Report } \\ \text { TWC } & \text { The Weather Channel } \\ \text { UAA } & \text { University of Alaska Anchorage } \\ \text { UAF } & \text { University of Alaska at Fairbanks } \\ \text { UNEP } & \text { United Nations Environment Programme } \\ \text { USACE } & \text { U.S. Army Corps of Engineers } \\ \text { USDA } & \text { U.S. Department of Agriculture } \\ \text { USDOI } & \text { U.S. Department of the Interior } \\ \text { USFS } & \text { U.S. Forest Service } \\ \text { USFWS } & \text { U.S. Fish and Wildlife Service } \\ \text { USGS } & \text { U.S. Geological Survey } \\ \text { WIF } & \text { Variance Inflation Factor } \\ \text { WU } & \text { Weather Underground } \\ & \end{array}$


THIS PAGE INTENTIONALLY LEFT BLANK 


\section{Appendix A: Data Sources}




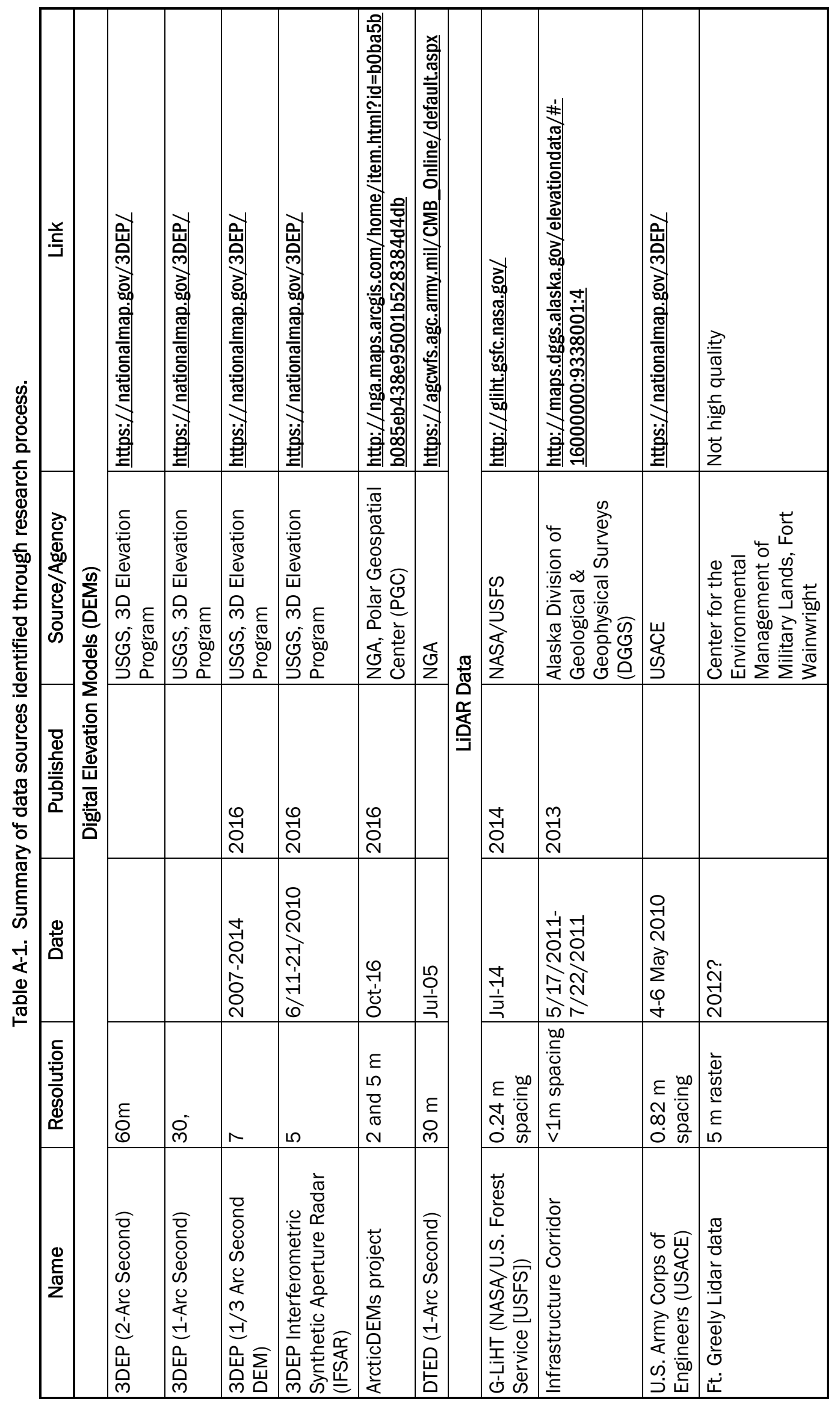




\begin{tabular}{|c|c|c|c|c|c|c|c|c|c|c|c|c|}
\hline . & & 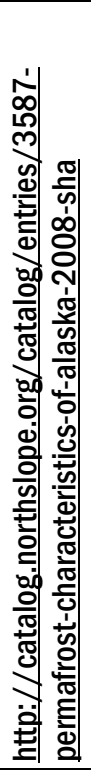 & 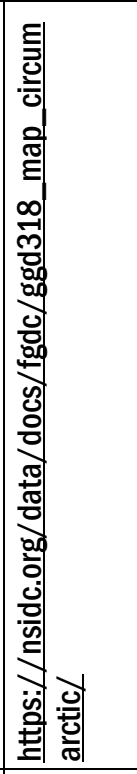 & 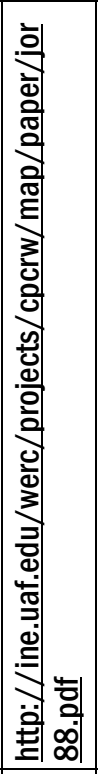 & 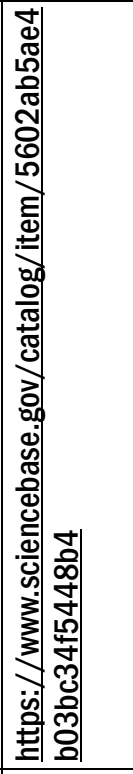 & 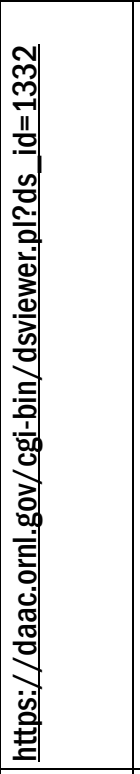 & 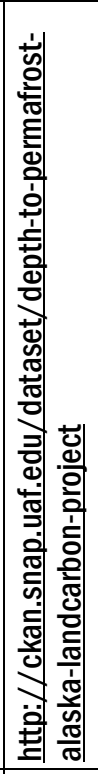 & 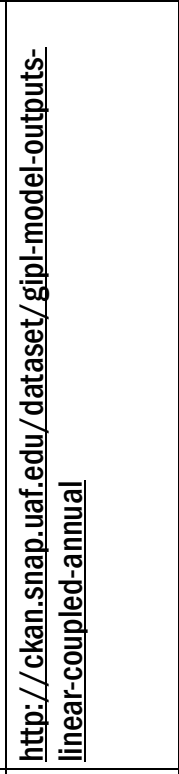 & 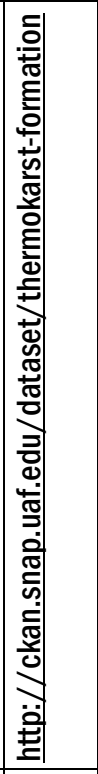 & 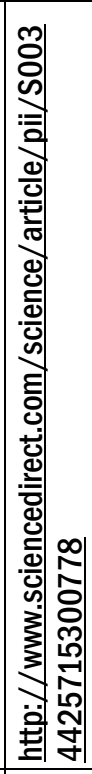 & 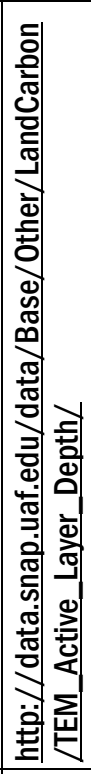 & 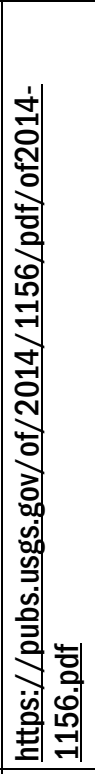 \\
\hline 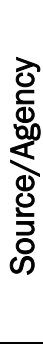 & & 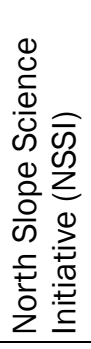 & 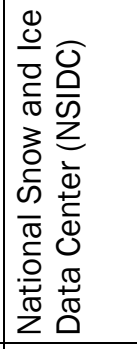 & 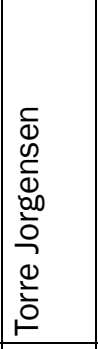 & 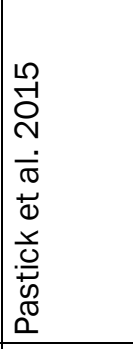 & 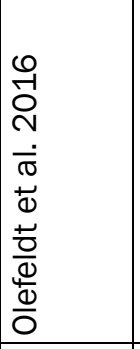 & 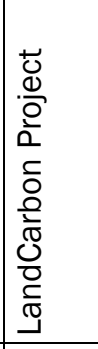 & 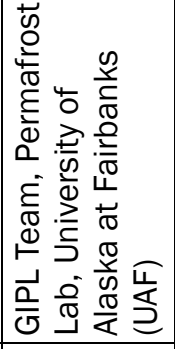 & & & & 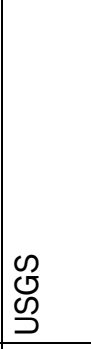 \\
\hline $\begin{array}{l}\frac{0}{d} \\
\frac{d}{0} \\
\frac{.0}{2} \\
\frac{0}{2}\end{array}$ & & & & & 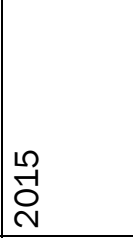 & & 공 & & & & & 공 \\
\hline$\frac{\Phi}{0}$ & & 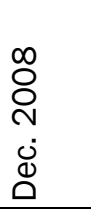 & $\begin{array}{l}\infty \\
\stackrel{8}{\circ} \\
\stackrel{-}{-}\end{array}$ & $\begin{array}{l}\infty \\
\Omega \\
\sigma \\
\sim\end{array}$ & 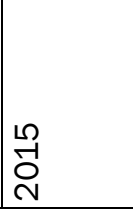 & 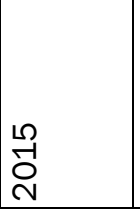 & テั & 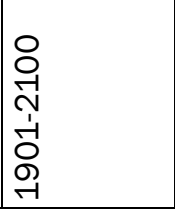 & 귱 & & & \\
\hline 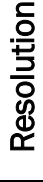 & & 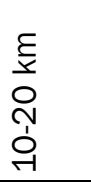 & 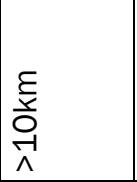 & 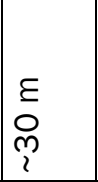 & $\begin{array}{l}\varepsilon \\
O \\
m\end{array}$ & 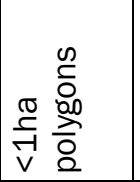 & $\begin{array}{l}8 \\
8 \\
8 \\
8 \\
\stackrel{0}{0} \\
\stackrel{+}{-1} \\
\end{array}$ & $\frac{\xi}{\frac{\varepsilon}{\gamma}}$ & $\frac{\xi}{\frac{\xi}{\partial}}$ & & & 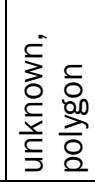 \\
\hline 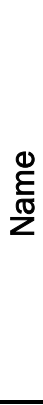 & 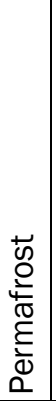 & 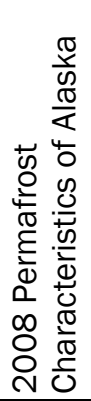 & 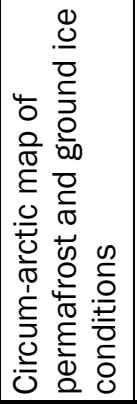 & 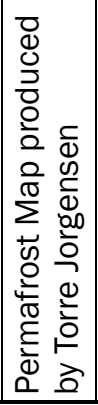 & 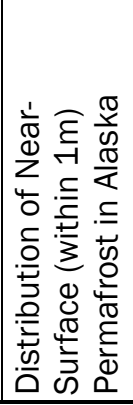 & 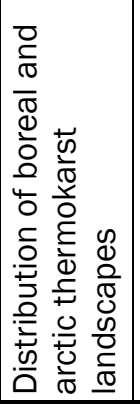 & 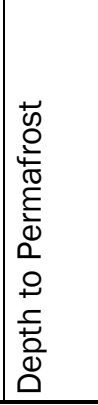 & 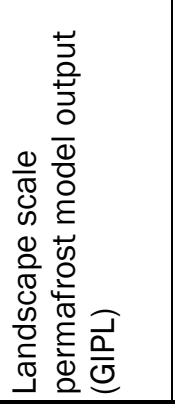 & 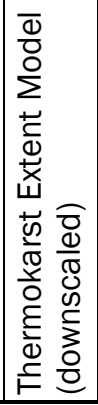 & 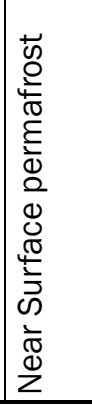 & \begin{tabular}{|l}
5 \\
0 \\
$\frac{0}{1}$ \\
0 \\
0 \\
0 \\
$\frac{0}{0}$ \\
0 \\
\\
\end{tabular} & 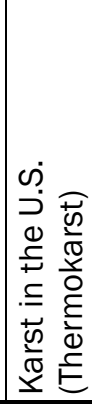 \\
\hline
\end{tabular}




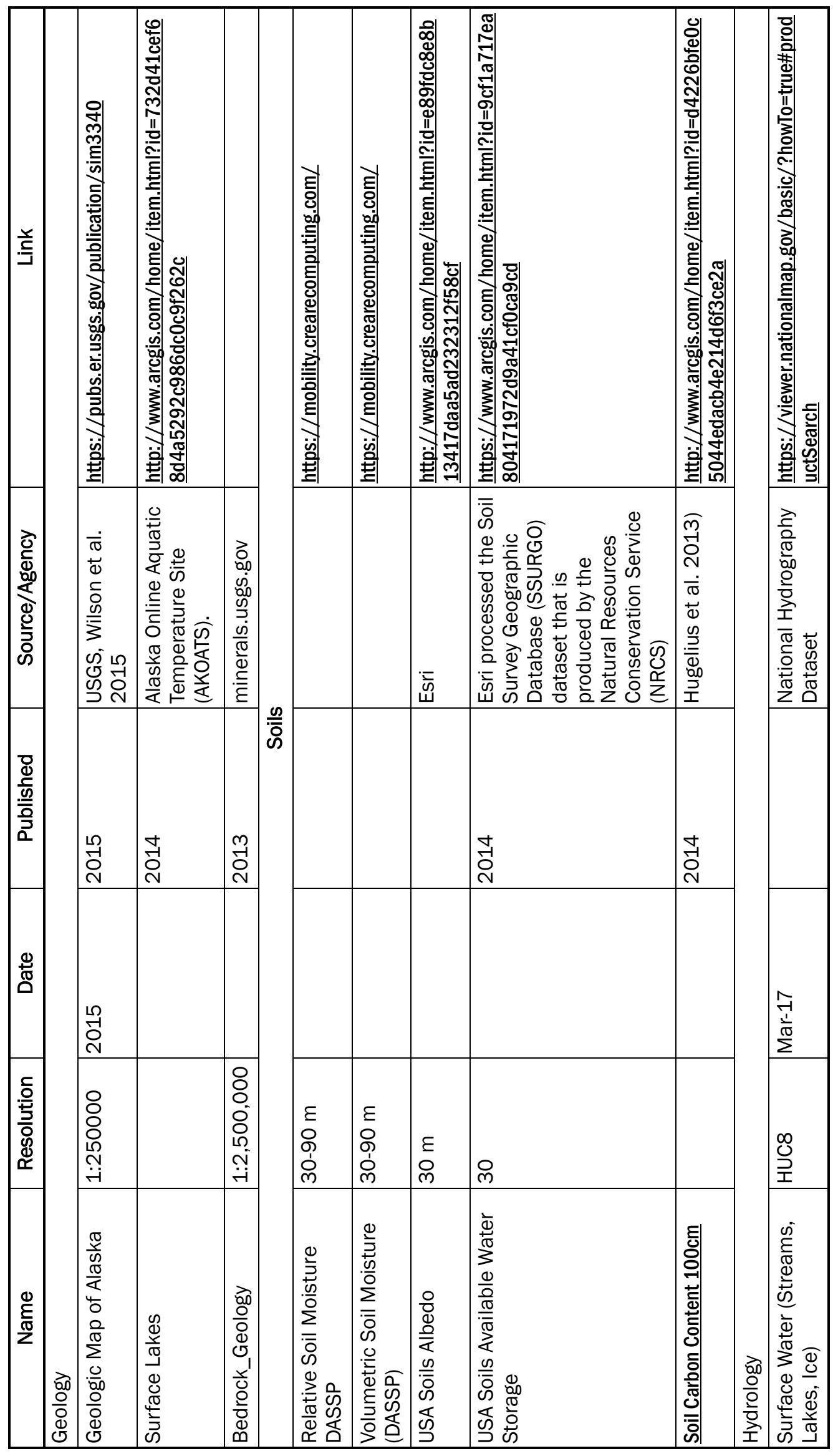




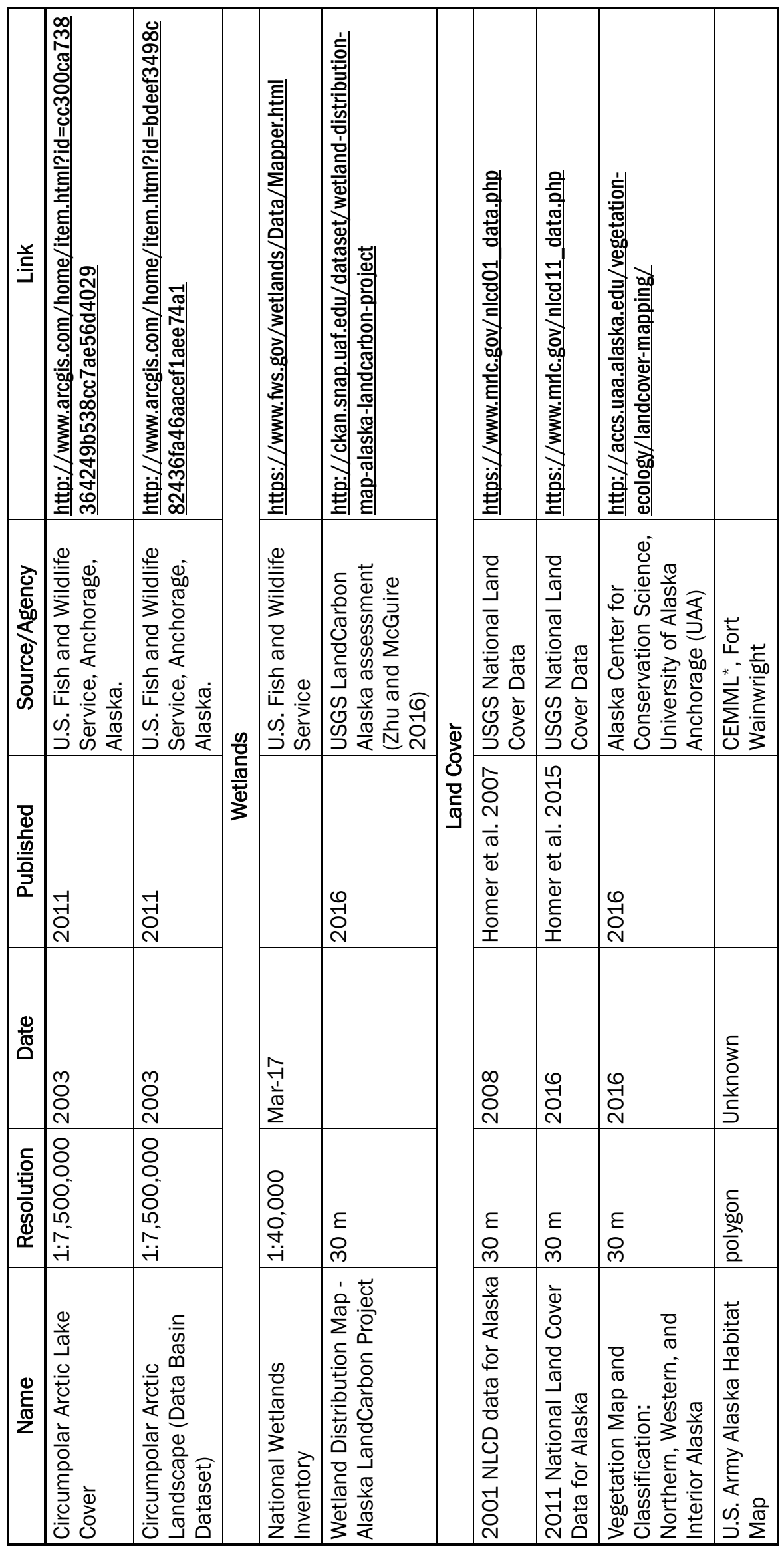

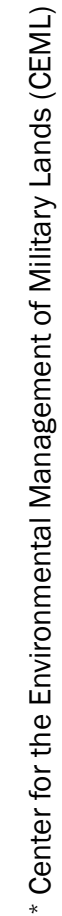




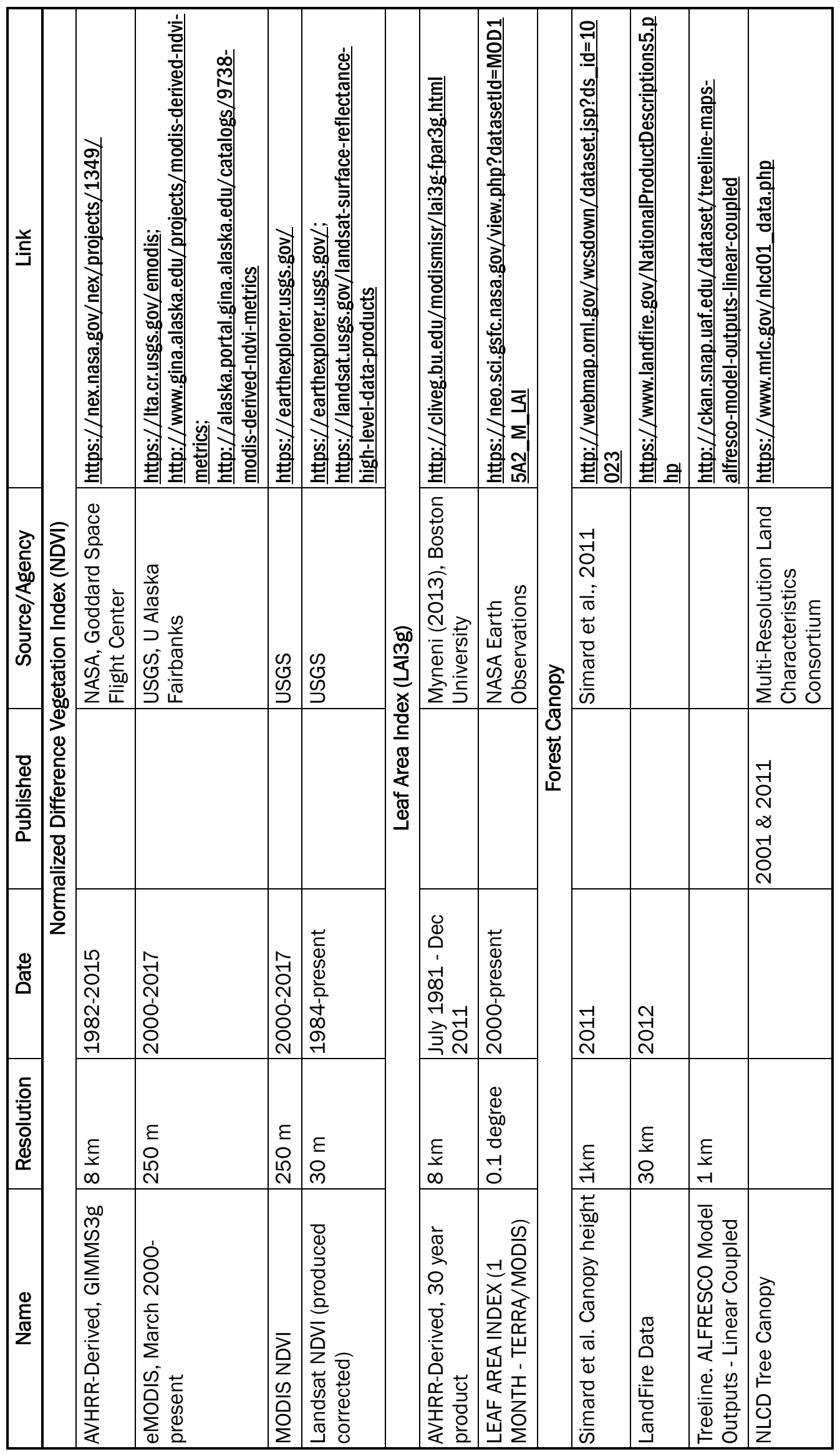




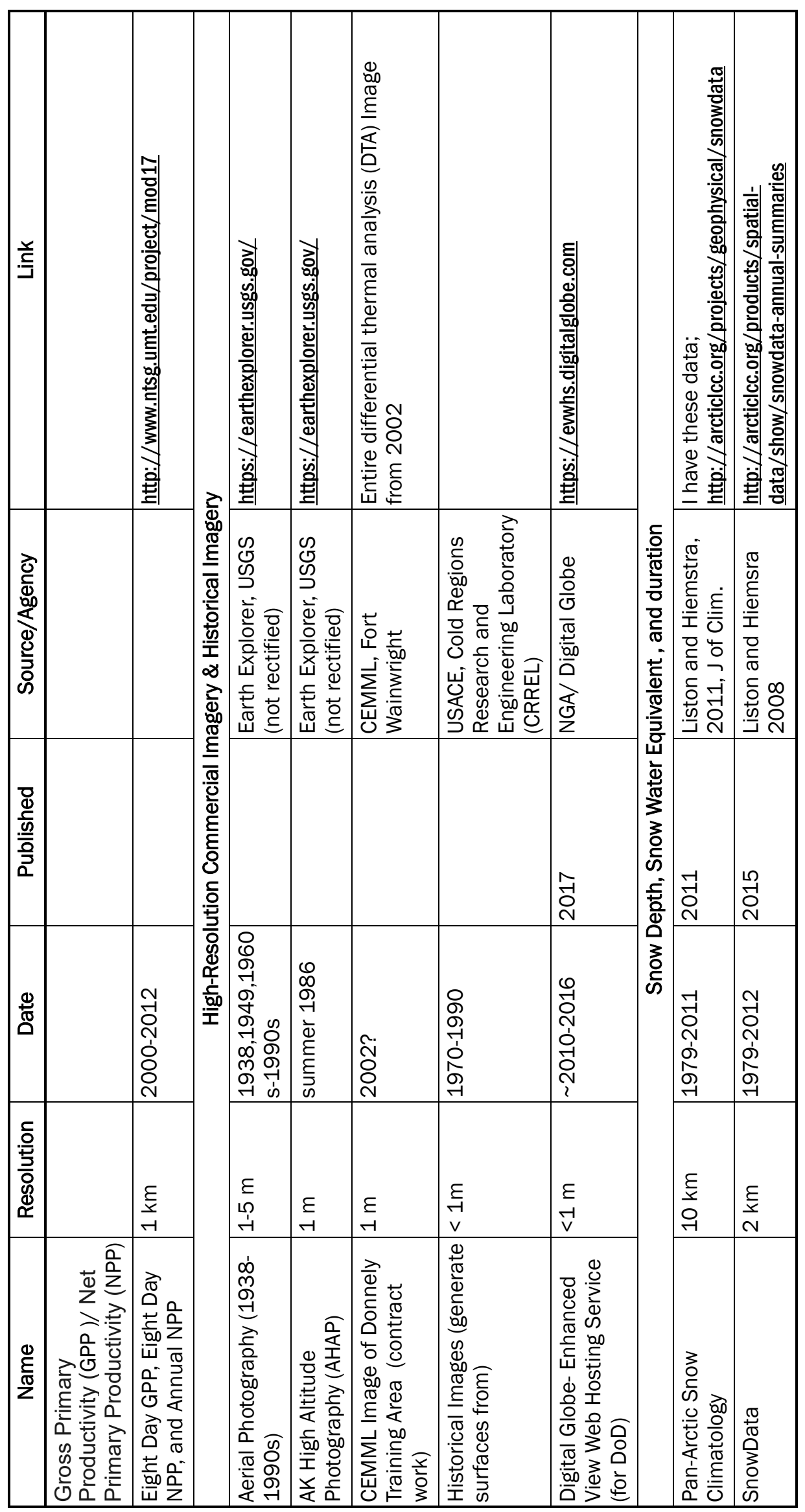




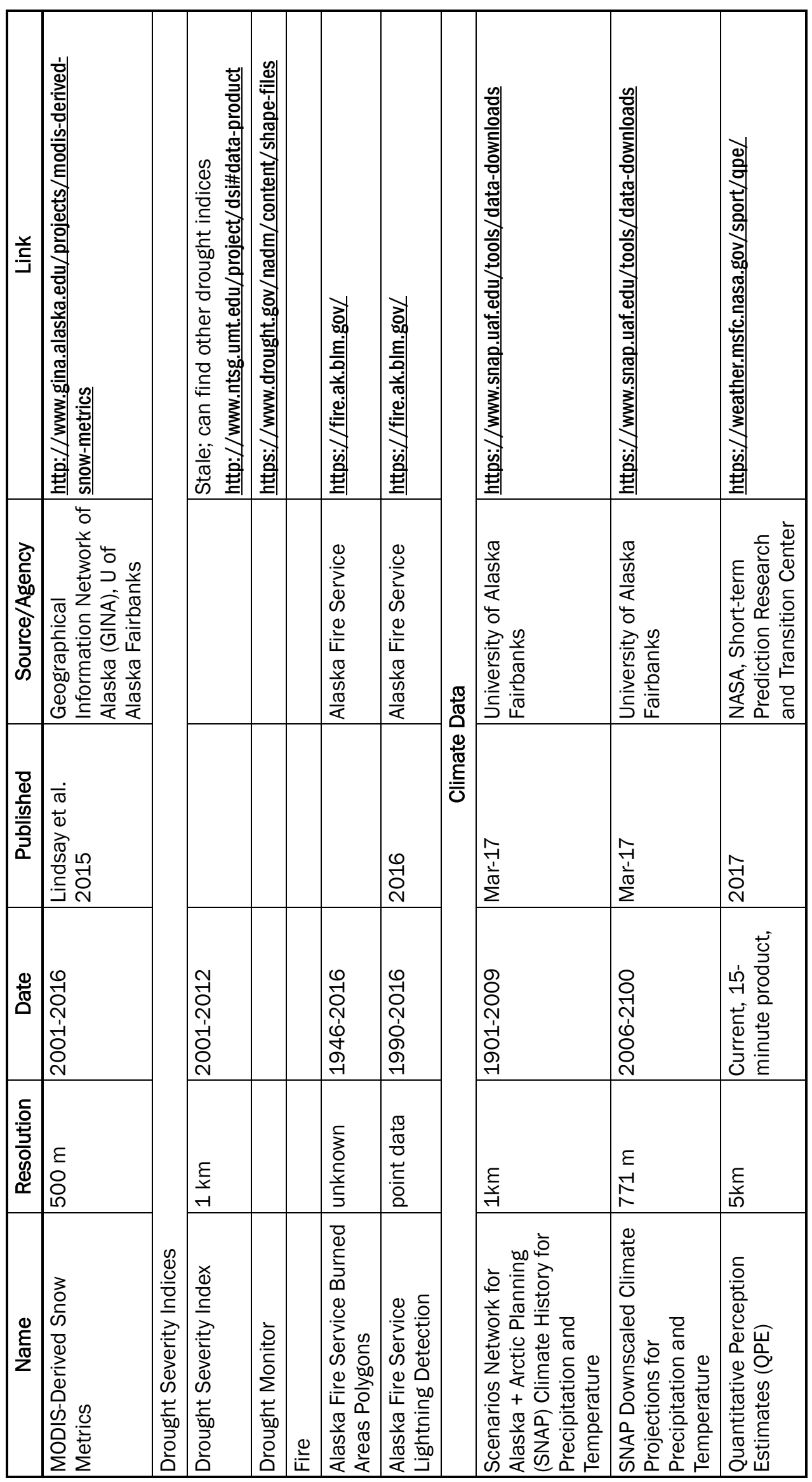




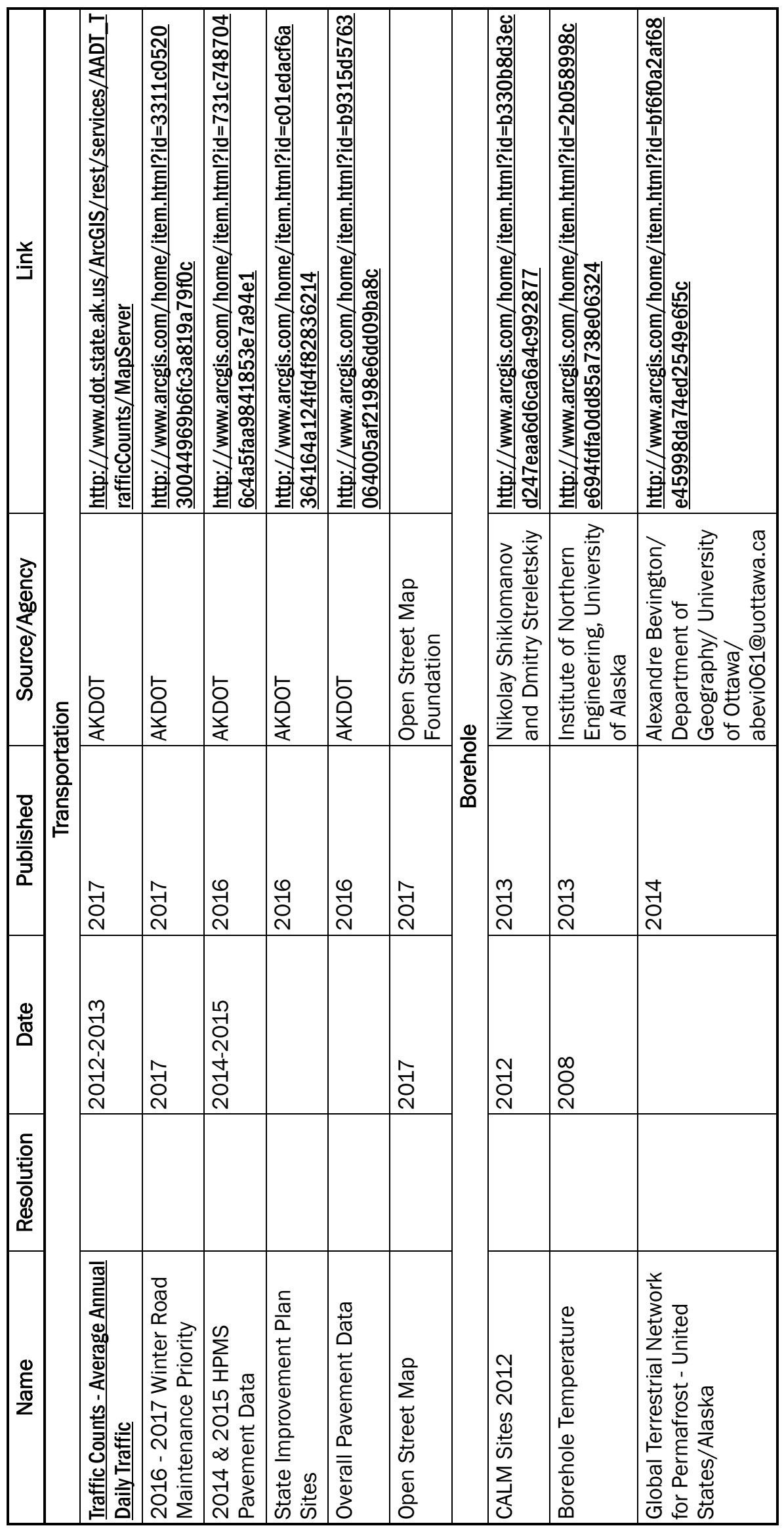




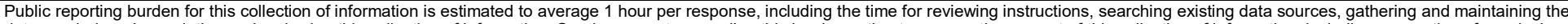

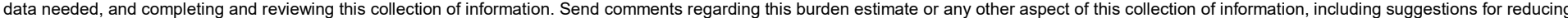

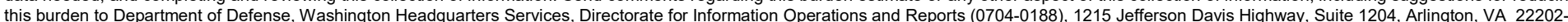

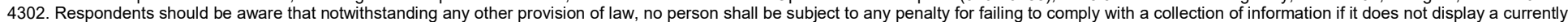
valid OMB control number. PLEASE DO NOT RETURN YOUR FORM TO THE ABOVE ADDRESS.
1. REPORT DATE (DD-MM-YYYY)
2. REPORT TYPE Final
$06 / 25 / 2018$

\section{TITLE AND SUBTITLE}

Permafrost and Road Degradation in Alaska
6. AUTHOR(S)

Juliana M. McMillan-Wilhoit, Heidi R. Howard, and Kate A. Morozova
3. DATES COVERED (From - To)

5a. CONTRACT NUMBER

\section{5b. GRANT NUMBER}

\section{5c. PROGRAM ELEMENT}

\section{5d. PROJECT NUMBER}

622720896

5e. TASK NUMBER

5f. WORK UNIT NUMBER

8. PERFORMING ORGANIZATION REPORT NUMBER

ERDC/CERL TR-18-12

Construction Engineering Research Laboratory (CERL)

PO Box 9005,

Champaign, IL 61826-9005

\section{SPONSORING / MONITORING AGENCY NAME(S) AND ADDRESS(ES)}

Assistant Secretary of the Army for Acquisition, Logistics, and Technology

600 Army Pentagon

Washington, DC 20310

10. SPONSOR/MONITOR'S ACRONYM(S)

ASA(ALT)

11. SPONSOR/MONITOR'S REPORT NUMBER(S)

\section{DISTRIBUTION / AVAILABILITY STATEMENT}

Approved for public release; distribution is unlimited.

\section{SUPPLEMENTARY NOTES}

\section{ABSTRACT}

Permafrost is rock, soil, or sediment that stays below $0 \mathrm{C}$ for at least 2 consecutive years. About a quarter of the northern hemisphere's land mass is permafrost, and Alaska may be $85 \%$ permafrost. Permafrost is degrading. Uneven thaw is expected to significantly add to the current costs of road, pipeline, and airport maintenance over the next 20 years in Alaska. In the Arctic, permafrost degradation may impact training activities and increase operations and maintenance costs annually at U.S. Army installations. This work outlines a methodology to predict the probability that local infrastructure will incur damage (i.e., if a road will crack) based on the probability that the infrastructure was built on a permafrost location.

\section{SUBJECT TERMS}

Permafrost-Alaska, Frozen ground-Alaska, Roads-Alaska, Roads--Maintenance and repair, Roads--Frost damage

\section{SECURITY CLASSIFICATION OF:}

\section{a. REPORT}

Unclassified

\section{b. ABSTRACT}

Unclassified c. THIS PAGE

Unclassified

\section{LIMITATION OF ABSTRACT}

SAR
18. NUMBER OF PAGES

58 19a. NAME OF RESPONSIBLE PERSON

19b. TELEPHONE NUMBER (include area code) 